Florida International University FIU Digital Commons

3-31-2011

\title{
Predicting the In-Term Persistence of Community College English-as-a-Second-Language Students
}

Carolyn A. Tonge

Florida International University, onecat9@bellsouth.net

DOI: $10.25148 /$ etd.FI1 1042606

Follow this and additional works at: https://digitalcommons.fiu.edu/etd

\section{Recommended Citation}

Tonge, Carolyn A., "Predicting the In-Term Persistence of Community College English-as-a-Second-Language Students" (2011). FIU Electronic Theses and Dissertations. 362.

https://digitalcommons.fiu.edu/etd/362 


\section{FLORIDA INTERNATIONAL UNIVERSITY}

Miami, Florida

\section{PREDICTING THE IN-TERM PERSISTENCE OF COMMUNITY COLLEGE ENGLISH-AS-A-SECOND-LANGUAGE STUDENTS}

A dissertation submitted in partial fulfillment of the requirements for the degree of DOCTOR OF EDUCATION

in

EDUCATIONAL LEADERSHIP AND POLICY STUDIES

by

Carolyn Tonge

2011 
To: Dean Delia C. Garcia

College of Education

This dissertation, written by Carolyn Tonge, and entitled Predicting the In-Term Persistence of Community College English-as-a-Second-language Students, having been approved in respect to style and intellectual content, is referred to you for judgment.

We have read this dissertation and recommend that it be approved.

Glenda D. Musoba

Thomas G. Reio, Jr.

Mohammed Farouk

Roger Geertz Gonzalez, Major Professor

Date of Defense: March 31, 2011

The dissertation of Carolyn Tonge is approved.

Dean Delia C. Garcia

College of Education

Interim Dean Kevin O’Shea

University Graduate School

Florida International University, 2011 
(C) Copyright 2011 by Carolyn Tonge

All rights reserved. 


\section{DEDICATION}

To Mom and Dad

Your commitment to my education and your faithful, loving encouragement of my

pursuit of this goal were my best reasons for not giving up. Though you could not wait on earth, I feel your smile from heaven as I announce: “Finally done!” 


\section{ACKNOWLEDGMENTS}

This journey has been very long, and often seemed like a never-ending mile. To every friend or colleague who shared an encouraging word along the way, thank you for helping to bear the burden if even for just that day. Special thanks to Dr. Peter Battaglia, whose frequent and encouraging words at just the right times made the difference.

Special thanks are due to my committee chair, Dr. Roger Geertz Gonzalez, who saw me through the last lap, and to my committee, Dr. Glenda Musoba, Dr. Thomas Reio, Jr., and Dr. Mohammed Farouk. Grateful memories go to Dr. Janice Sandiford, for her generous encouragement as she walked the first half of this mile with me. Special gratitude is extended to Dr. Abbas Tashakkori, without whose mentoring and support, both the journey and the conclusion would have been altered. Together, Dr. Len Bliss and Dr. Linda Bliss gave me the best appreciation and preparation for a mixed-methods design. I am grateful to both of you for generously sharing your passion.

Deep words of gratitude are inadequate but still expressed to my husband, Eustace, and my son, Adam, who never complained but only encouraged me. I am, first and last, most grateful to my God, who gave grace sufficient for all my needs. 


\title{
ABSTRACT OF THE DISSERTATION \\ PREDICTING THE IN-TERM PERSISTENCE OF COMMUNITY COLLEGE ENGLISH-AS-A-SECOND-LANGUAGE STUDENTS
}

\author{
by \\ Carolyn Tonge \\ Florida International University, 2011 \\ Miami, Florida \\ Professor Roger Geertz Gonzalez, Major Professor
}

The English-as-a-second-language (ESL) community college student population has increased notably in the past decade, but a decreasing number of these students are completing courses, programs, or degrees (Erisman \& Looney, 2008). These students come to college with unique background experiences, and once in college, deal with challenging linguistic, academic, and social integration issues. Though they are not linguistically homogenous, and they do not have a common purpose, ESL students share the common goal of attending community college to learn to speak English (Szelényi \& Chang, 2002). Course completion is a primary measure of progress toward that goal, and is therefore an issue of concern for both ESL students and community colleges, which continue to be the access point for language-minority students progressing into higher education (Laden, 2004).

The purpose of this study was to investigate the factors that predict in-term persistence of community college ESL students. A mixed methods research design consisting of two phases was utilized, and participants in this study were ESL students enrolled in a large community college in south Florida. Phase 1 students completed the 
Community College ESL Student Questionnaire (CCSEQ), which collected demographic data and data on entry characteristics, academic integration, and social integration. Discriminant and descriptive analyses were used to report the data collected in Phase I. Phase 2 students were a matching cohort of completing and non-completing students who participated in semi-structured interviews at the end of the term. Data collected in the interviews were analyzed thematically, using a constant comparative method as described by Glaser and Strauss (1967).

Students’ self reported demographic data, background characteristics, goal commitment, and integration factors on the CCSEQ showed no significance between the students who completed the term and the students who did not complete the term. However, several differentiating themes emerged from the interview data, which indicated differences in goal commitment and integration between the two groups. The focus of non-completers on getting good grades rather than completing the course, and the commitment of completers to the goal of finishing the class in order to go forward, both raise questions for future research studies. 


\section{TABLE OF CONTENTS}

CHAPTER

PAGE

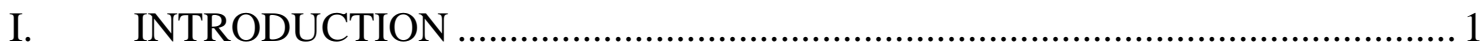

Community College Mission ................................................................................... 1

Characteristics of Community College Students ................................................... 3

Community College Language-Minority Students …………………………...... 4

Persistence of Language-Minority Students in Community Colleges ................... 7

Statement of the Problem...................................................................................... 10

Theoretical Framework .................................................................................. 11

Research Question .................................................................................. 14

Definition of Terms....................................................................................... 14

Significance of the Study ..................................................................................... 16

Delimitations of the Study .............................................................................. 17

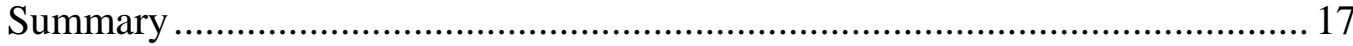

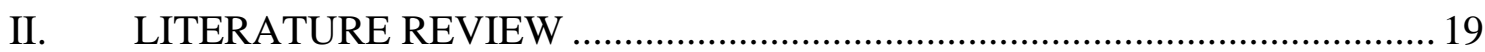

Persistence Theories........................................................................................ 19

Tinto's Theory of Student Persistence...................................................... 19

Bean's Model of Persistence Behavior .................................................... 21

Research on College Student Persistence …………………............................... 23

Research on the Persistence of Community College Students ............................ 28

Persistence Among Nontraditional Community College Students ....................... 36

Persistence Among Language-Minority Community College Students ............. 41

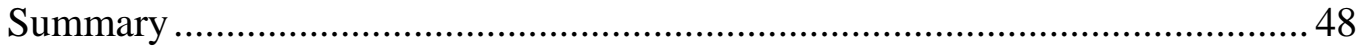

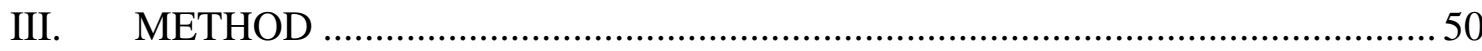

Research Design........................................................................................... 50

The Research Setting …………………………………................................... 50

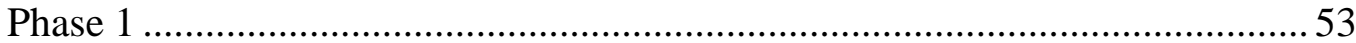

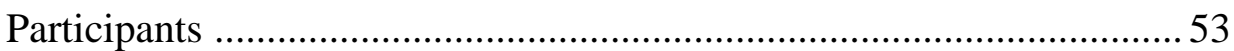

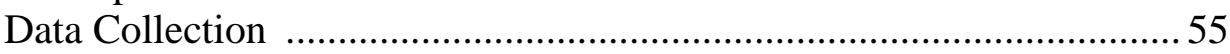

Variables and Measurement...................................................................5 57

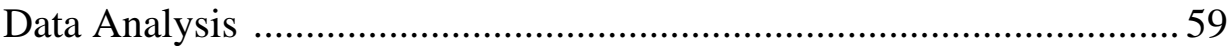

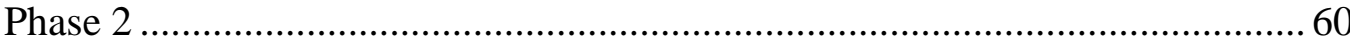

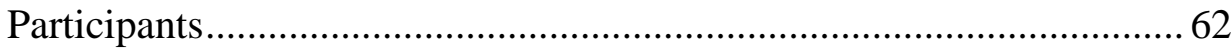

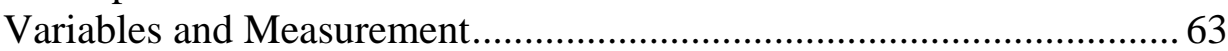

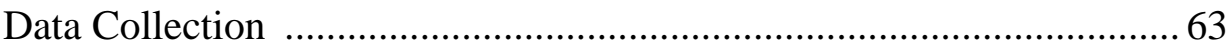

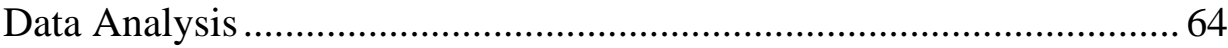

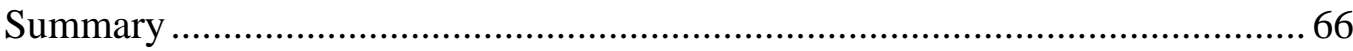

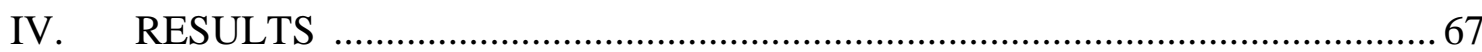

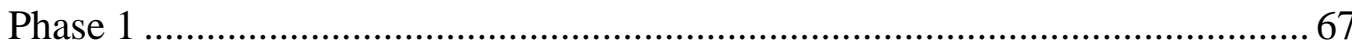

Background and Entry Characteristics...................................................... 68 
Goal Commitment .......................................................................... 73

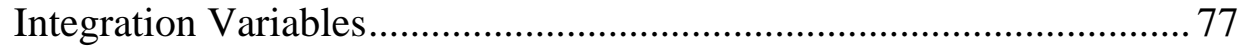

Summary of Phase I Results ................................................................... 84

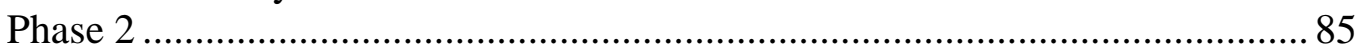

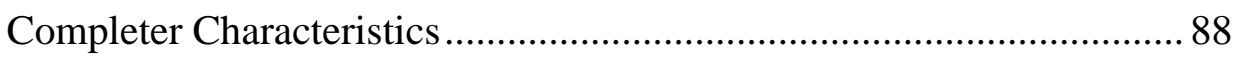

Completer Concerns ..................................................................... 91

Completer Recommendations .......................................................... 92

Non-completer Characteristics.......................................................... 93

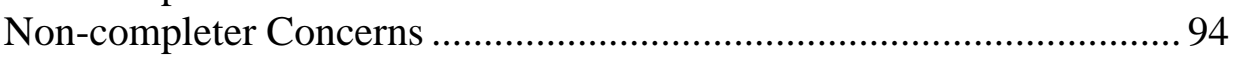

Non-completer Recommendations................................................... 95

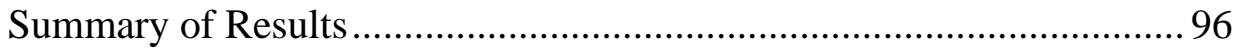

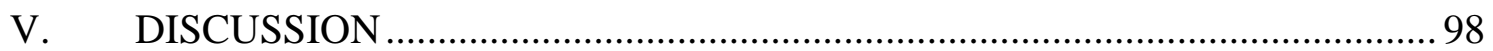

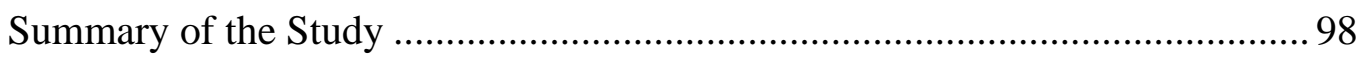

Background and Purpose of the Study ................................................. 98

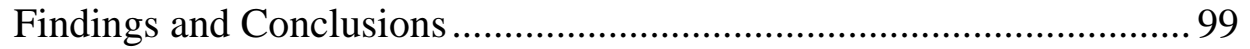

Recommendations for Future Research .................................................... 101

Implications for Practice ........................................................................ 102

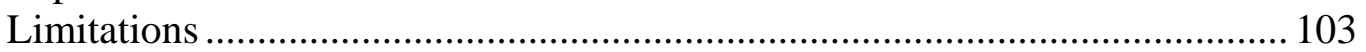

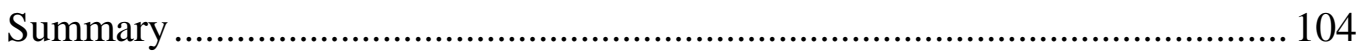

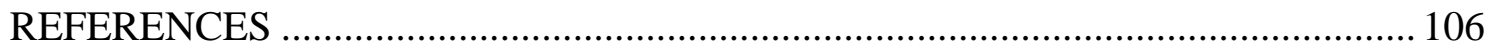

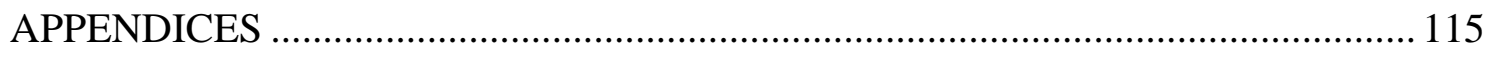

VITA 


\section{LIST OT TABLES}

TABLE

PAGE

1. Sample of ESL Demographic Information-

Broward College Central Campus ............................................................... 54

2. Phase I Variables, Sources, and Categories ................................................. 58

3. Frequency Distributions for Pre Entry Characteristics ..................................69

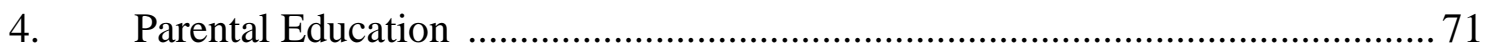

5. Test of Equality of Group Means for Pre Entry Characteristics ........................ 73

6. Frequency Distributions for Goal Commitment Variables .............................. 75

7. Test of Equality of Group Means for Commitment Variables ......................... 77

8. Frequency Distribution for Integration Variables.......................................... 78

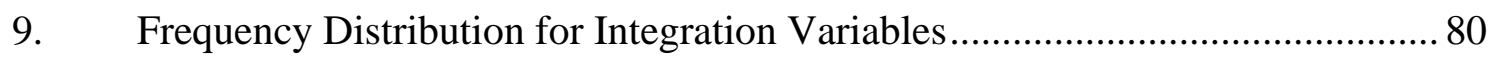

10. Test of Equality of Group Means for Integration Variables ............................ 80

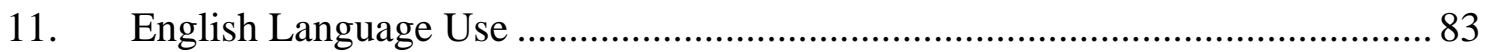

12. Test of Equality of Group Means for English Language Use.......................... 84

13. Demographic Information, ESL Level, Registration Time, and GPA of Interviewees...................................................................... 87

14. Reasons for Not Completing the Course ..................................................... 95 


\section{Chapter I}

\section{Introduction}

This study investigated selected factors that predict in-term persistence to course completion in English for Academic Purposes (EAP) courses for language-minority students at a large community college in south Florida. A mixed methods research design was used. Demographic information and students' self-reported activities were collected, using the Community College ESL Student Questionnaire (CCESQ). Also, a sample of students who withdrew during the semester and a corresponding sample of students who completed the term, were invited to participate in semi structured interviews. This chapter presents the problem, purposes of the study, theoretical framework, and research questions. It concludes with the operational definitions of terms, significance of the study, delimitations, and summary.

An increasing number of English-as-a-second-language (ESL) students are attending community colleges for the specific purpose of learning to speak English, but a decreasing number of these students are completing courses, programs, or degrees (Erisman \& Looney, 2008). The goal of this study was to investigate selected variables that predict language-minority students' in-term persistence and differentiate those students who complete the term from those students who do not.

\section{Community College Mission}

Community colleges are an essential part of the American system of higher education, serving the educational needs of many communities and providing open access for students who are economically, socially, culturally, academically, or linguistically 
nontraditional. Community colleges are accessible in terms of location, tuition, admission, and curricula that include credit and noncredit training and development. They offer programs ranging from transfer degrees to ESL to skill retraining to community enrichment programs or cultural activities (American Association of Community Colleges [AACC], 2005). Almost half (46\%) of all undergraduate students in the United States are enrolled in community colleges. Without this opportunity, millions of students would not be able to pursue an education beyond high school.

Community colleges were originally designed to encourage additional education for those who could not gain access to a university, who could not afford a 4-year college education, or who were reluctant to leave home and go away to college. In the early 20th century, rapidly-growing public high schools were seeking new ways to serve their communities; the resulting solution was to add needed programs like teacher training, vocational education, or citizenship training to the high-school diploma program. At the same time, small private, 4-year colleges had fashioned an effective model of higher education grounded on the principles of small classes, close student-faculty relations, and a program that included both academics and extracurricular activities. The earliest community colleges emerged from the combination of these traditions, and in the early years, the colleges focused on general liberal arts studies. It was President Harry S. Truman who instituted the President's Commission on Higher Education in 1946, in part, to study the developing trend of the 2-year college. The Truman Commission found that " $49 \%$ of the general public had the intellectual capacity to continue their high school education for an additional two years” (Witt, Wattenbarger, Gollattscheck, \& Suppger, 1994, p. 130). The term community college was initiated by the idea that these institutions 
would be established in local communities with funding support from each state. Community colleges became a national network in the 1960s with the opening of 457 public community colleges, and at present, there are 988 public community colleges in the country (AACC, 2009).

The future of community colleges necessarily includes their increasingly important role in the higher education system of the U.S. This role is driven by the dramatic increase in student diversity in American postsecondary education (Pascarella \& Terenzini, 1998). The historic mission of the community college to provide access to higher education for all has not changed. Though the population served by these colleges is continually changing, the need for access to higher education remains the same.

\section{Characteristics of Community College Students}

When compared to other institutions of higher education, the composition of the community college student body is unique. The diversity of goals and intentions with which students enroll in community colleges include obtaining a degree or certificate, preparing to transfer to the university, preparing for a career, acquiring or improving a skill, or learning English as a second language. Beyond this diversity of goals and intentions, community colleges are challenged to address the needs of an increasingly racially, ethnically, and linguistically diverse student population. Recently Rumbaut and Portés (2001) observed that "the new immigration to the United States ... is unprecedented in its diversity of color and class and cultural origins” (p. 1). As current and projected enrollments suggest that the community colleges will continue to be the campus of choice and access to higher education for the majority of these new immigrants, community colleges are called to rise to the challenge and "educate those 
whose cultural heritage/interest/racial group identities are positively affirmed in our racially stratified society, along with those whose are not; and educate those who are white, and those who are not” (Betances, 2004, p. 44).

\section{Community College Language-Minority Students}

Given this rapid increase in the general minority student population, and specifically in the language-minority student population, the community college must be careful that its open door policy unquestionably avoids becoming a revolving door. Title VI of the Civil Rights Act of 1964 stipulates that students cannot be excluded from participation in, denied the benefits of, or subjected to discrimination in educational programs or activities on the basis of race, color, or national origin. In 1968, the Department of Health, Education and Welfare published guidelines to the effect that school systems are responsible for assuring that students of a particular race, color, or national origin are not denied the opportunity to obtain the education generally obtained by other students in the system. Along with access, specific investment of effort and resources are being devoted to the enhancement of language-minority student success. This challenge is owned by both the college and the students, inasmuch as a student's persistence is the result of a collaborative effort. The diversity of the community college language-minority student body includes a variety of learning styles, socioeconomic backgrounds, and cultural and linguistic orientations.

In 2000 , Hispanics represented $12.5 \%$ of the general population. Following a $58 \%$ growth between 1990 and 2000, Hispanics edged out African Americans to become the largest single non White racial/ethnic group. Latinos are the fastest growing racial/ethnic group in the country, and when Latinos attend college, they are most often enrolled in 
community colleges (White House Initiative, 2000). In the same 1990-2000 decade, the population of Asian Americans, Native Hawaiians, and other Pacific Islanders increased by $52 \%$ to become the second fastest growing racial/ethnic group in the United States (Laden, 2004). Presently, nearly 20\% of the general population live in a household where a second language other than English is spoken, and in more that $75 \%$ of these homes, the second language is Spanish. Florida ranks fourth among the six states with the highest concentration of immigrants; the others are California, New York, Texas, New Jersey, and Illinois (Davis-Wiley, 2002). Each of these states serves proportionate numbers of ESL students in its local community colleges.

Once enrolled in college, many language-minority students realize that they lack the necessary language skills to take advantage of this open door opportunity. Specifically, they lack the required English language proficiency for college readiness. According to Szelényi and Chang (2002), “The challenge for educational institutions, including community colleges, lies in finding appropriate ways of responding to the diversity of backgrounds and needs these students represent” (p. 57). The strategies for identifying and addressing the causes of academic non readiness in language-minority students are as diverse as the students they address. This often results in misplaced support services, frustrated and disappointed students, and retention outcomes that fall far short of expectations. Lewis’s (2009) search for the “disconnect between institutional measures of success and ESL learners’ perspectives on their learning goals and success as community college students” (p.160), identified the desire to develop a skill or knowledge set as the most frequently expressed student intention or goal. 
Although much of the research done with language-minority students has been focused on Hispanics, community colleges are serving students with a much greater variety of primary languages and cultures than Spanish and Hispanic. ESL students are not homogeneous; in fact, the number of linguistic and cultural factors that come to bear on the persistence and success of language-minority students exceed the boundaries of what has been measured by the existing body of research on this topic. In fact, no comprehensive national data source exists that can produce an accurate description of immigrants at American community colleges (Szelényi \& Chang, 2002). Chase and Mahoney (1996) reported on the most inclusive study undertaken to enumerate immigrant students attending community colleges, done by the American Association of Community Colleges (AACC) in 1995. The AACC requested 1,154 of its 2-year member colleges to provide information on the number of immigrant and international students enrolled in their programs. The definition of immigrant status used by the AACC was limited to legal permanent residents, undocumented aliens, and refugees, and excluded naturalized United States citizens. Only 624 colleges responded, and only 476 of those reported on their foreign-born population. At that time, the highest number of legal permanent residents was reported by community colleges in California, Florida, Maryland, Washington, DC, and New York.

Bailey and Weininger (2000) have reported that the most comprehensive effort done to document immigrant students was a system-wide institutional research report at the City University of New York (CUNY), which contains information on all foreignborn individuals regardless of the age at which they established residency in the United States. CUNY's public higher education system includes 2- and 4-year colleges as well as 
several associate degree programs within the 4-year schools. The research at CUNY revealed that immigrants who had earned their high school diplomas abroad were somewhat more likely to be enrolled in a 2-year program.

\section{Persistence of Language-Minority Students in Community Colleges}

Despite the rising language-minority student population attending community colleges, their low persistence, completion, and associated degree attainment rates create obstacles to their academic success. In addition to factors identified in Tinto’s (1996) framework of academic and social integration, the research has uncovered several factors related to enhancing language-minority student persistence. Rendón (2002) contends that validation is more significant than integration as an influence on the persistence and success of nontraditional and underserved students. Goal commitment was identified by Romano (1995) as one of the two most significant predictors of academic success for Hispanic women. The role and effect of critical mass on Latino community college students’ success was established by Hagedorn, Chi, Cepeda, and McLain (2007) as a positive influence encouraging minority students to higher academic performance. DavisWiley (2002) asserts that proper teacher preparation, to include personal experience with other cultures, will enhance retention and academic success. Adequate support service for ESL students (Ellis \& Stebbbins, 1996), accurate English language level placement (Faltis, 2001), and proper tracking of ESL students (Rodriguez, 1996) have also been presented as significant contributors to the persistence and academic success of languageminority students.

It is the nature of immigrants to concentrate in large cities and metropolitan areas, and ESL students tend to concentrate in urban areas. Nationwide statistics indicate that in 
1999, 55\% of the nation's community colleges, including those serving large cities and metropolitan areas, were providing ESL instruction (Schuyler, 1999). Laden (2004) reports that ESL students are especially concentrated in the four most populous states of California, Texas, Florida, and New York, and southeast Florida has one of the highest concentrations of ESL students in the nation. For example, in 2007 Miami Dade College (formerly Miami Dade Community College) reported an enrollment of 165,000 students on its seven campuses, $66 \%$ of whom are Hispanic. Among the students enrolled at Broward Community College in Florida in 2007, there were speakers of over 100 primary languages other than English. Though the language-minority students in southeast Florida are predominantly primary speakers of Spanish, the linguistic and educational backgrounds of these ESL students vary enormously. Though goals and intent vary, this large and growing number of language-minority students comes to the community college with a common need to learn to speak English.

Virtually every category of immigrant student can be found among the languageminority students in Dade and Broward counties of southeast Florida: international students, foreign students, resident aliens, asylum seekers, refugees, and vast numbers of generation 1.5 individuals. This latter category identifies U.S.-educated foreign-born ESL students, whose spoken English flows easily and often includes idiomatic expressions that are common to native speakers; however, their grammar and pronunciation consistently contain second-language errors (Blumenthal, 2002). In order to facilitate these students' persistence and success, the community college must successfully address a three-part challenge: students' intent, students' unique cultural and linguistic background, and students' immigration category. Awareness of the students' immigration 
status helps the college to plan and provide the appropriate advisement support that is necessary for different categories of immigrant students.

The traditional community college ESL program is designed either for the student who plans to transfer to the university or needs to learn enough English to gain employment. For the former group, the community college provides access to higher education by providing remediation or language proficiency instruction. For the latter group, it provides intensive English instruction that opens the door to vocational opportunities. Though these students fall into different categories of limited English proficiency and have different needs, they have one common goal: to achieve a measure of competency in the English language. Community colleges have been purposeful and committed in meeting the academic needs of this student population with varying degrees of success. In addition to reviewing and revising ESL curricula, colleges have improved and increased the support services to ESL students in an effort to facilitate the realization of their goal.

However, there continues to be a general disregard for the impact of nonacademic issues that help or hinder ESL students in their pursuit of academic success. Current persistence studies focus either on term-to-term or year-to-year retention, with emphasis on what happens in the classroom. As the smallest unit of persistence, in-term persistence or course completion warrants attention in the overall assessment of student retention, and is currently missing from the body of available research. Additionally, much of what goes into a successful academic experience for these students happens apart from direct classroom instruction; it is therefore important to look at these non curricular variables with a view to assessing their impact on in-term persistence and eventual academic. The 
goal of this study was to explore the possible academic, social, and personal variables that are associated with in-term persistence and therefore directly or indirectly impact the academic success of ESL students at the community college.

\section{Statement of the Problem}

Community colleges continue to be the access point for language-minority students progressing into higher education, the workforce, or English language proficiency. Students' persistence and success in ESL programs are dependent on many factors, some that have been identified and measured and others that remain undetected and untouched. Persistence studies most often look at persistence to graduation, and less often at term-to-term persistence. Almost by definition, only those students who complete the term and re-enroll will eventually persist to graduation or program completion, therefore those variables that predict in-term persistence are valuable for predicting overall persistence. Predicting in-term persistence provides opportunities for immediate intervention, not possible in graduation studies. If students persist from start to end of term, they are more likely to re-enroll; and if they re-enroll, they are more likely to graduate. Previous research has shown that some of the variables that predict persistence in community college students in general include entry characteristics, goal commitment, and academic and social integration. However, few studies have focused generally on predictors of in-term persistence, or specifically on predictors of in-term persistence for ESL community college students. Consequently, this study responded to the need to focus specifically on language-minority students at the community college and the variables that predict persistence for this specific student population. Identification of factors that predict students' in-term persistence will enable the college studied, and 
hopefully similar institutions, to better facilitate students' overall persistence and success by designing intervention and prevention programs.

\section{Theoretical Framework}

Tinto’s (1993) model of institutional departure asserts that academic and social integration of the individual into the culture of the institution drives continued enrollment and program completion. Other researchers (Fox, 1986; Mulligan \& Hennessy, 1990; Pascarella \& Chapman, 1983) found that for 2-year college students, academic integration was a significant positive influence on persistence, whereas social integration was negatively associated with persistence. Bean and Metzner’s (1985) model of persistence reduces the importance of social integration but identifies an academic variable (first semester grade point average [GPA]) as a significant contributor to student persistence.

Despite the broad appeal of Tinto’s (1993) theory, empirical research provides only modest support for its propositions (Braxton \& Lee, 2005). Critics argue that the theory fails to recognize cultural variables, making it a poor fit when applied to minority students (Guiffrida, 2006; Rendón, Jalomo, \& Nora, 2000). For example, Tinto advocates the need to "break away" from past associations and traditions to become integrated into the college's social and academic environment. His opponents argue that this assimilation/enculturation paradigm ignores bicultural integration or the ability of minority students to succeed at college while being part of both the majority and minority cultures (Rendón et al., 2000). Tanaka (2002) suggests that cultural bias seems embedded in Tinto's concept of integration, in that it implies assimilation to dominant norms and a mainstream college environment. 
Tinto's (1993) conceptualization of student commitment, a construct that stands at the core of the theory, asserts that students enter an institution with certain background characteristics that have shaped their levels of commitment for completing their degree. Additionally, these levels of commitment are continually shaped by the students' interactions within the academic and social systems of the institution. While commitment is central to Tinto's theory, it does not explain students' motivational orientations to commitments (Stage, 1989), which is an important limitation when considering the persistence and academic achievement of minority students. The background characteristics that shape levels of commitment and influence integration are only part of the driving force to persist; the other, and perhaps more significant part, is embedded in students' motivational orientation. Stage identified motivational types to include social relationships, external expectations, social welfare, professional advancement, escape, stimulation, and cognitive interest. Recognizing the lack of social and cross-cultural psychological principles in Tinto’s theory, Guiffrida (2006) affirmed that these would strengthen Tinto's theory, enhance its cultural sensitivity and make it more descriptive of minority student academic achievement and persistence. Figure 1 represents the inclusion of motivational orientation as the filter through which background characteristics, performance, and orientation might influence student persistence and success. 


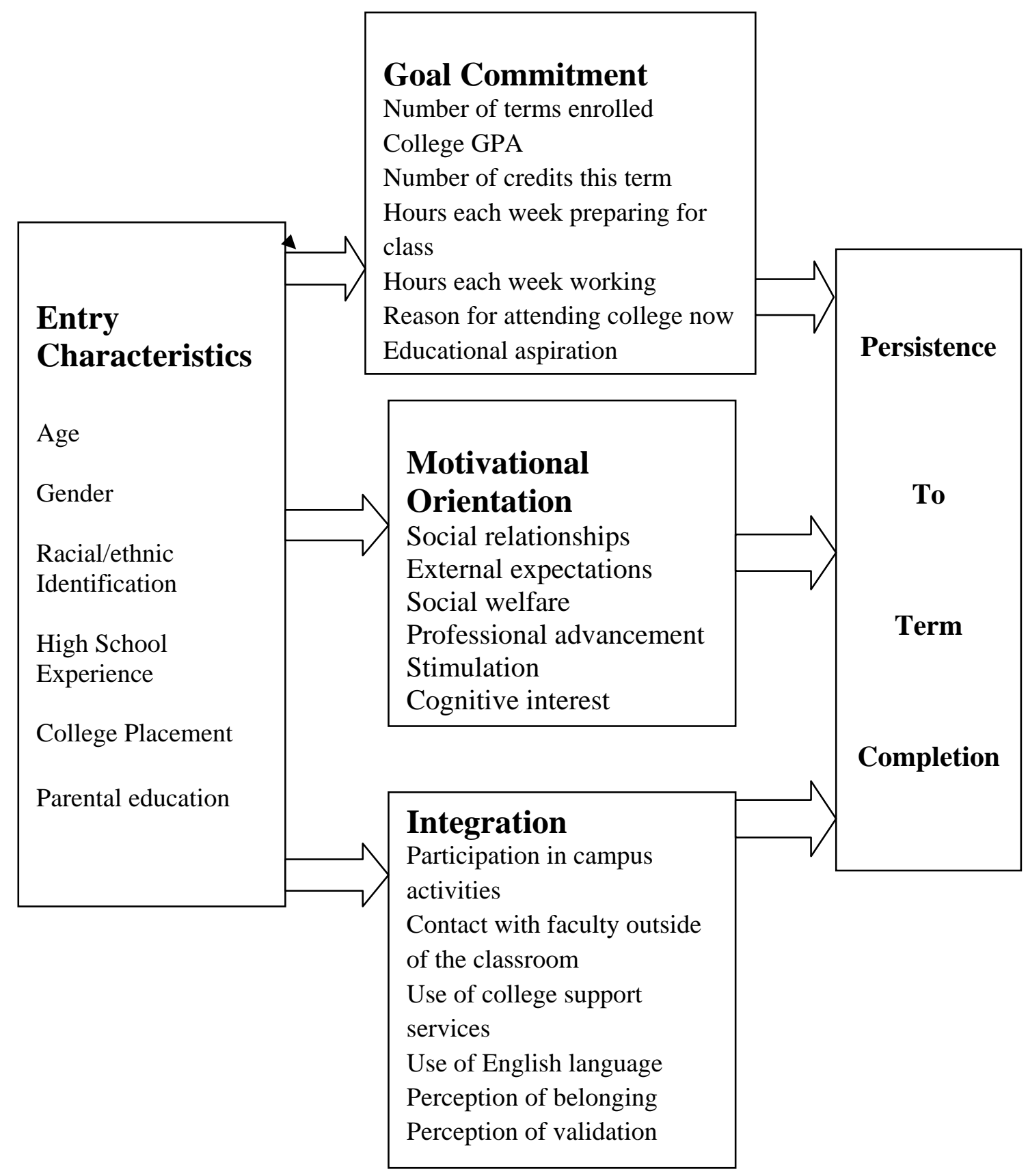

Figure 1. Variables and their theoretical relationship to students’ persistence. 


\section{Research Question}

The main research question of interest in this study was:

Which selected factors differentiate ESL students enrolled in an English for Academic Purposes Program at a particular South Florida community college who persist to term completion from those who do not persist to term completion?

\section{Definition of Terms}

Attrition is the number of students who do not return to school after each semester.

Students are subject to voluntary attrition (an individual decision not to re-enroll) or involuntary attrition (an institutional decision to suspend or dismiss).

Dropout is a student who stopped attending prior to accomplishing an educational goal and specifically communicated that s/he no longer planned to work toward that goal.

Emerging majority is a term used to describe the still-growing, highly diverse, culturally distinct student groups that are now populating community colleges.

English for Academic Purposes (EAP) is a course of study designed to prepare students whose primary language is not English to pursue an academic college program or degree using the English language.

Generation 1.5 is used to identify immigrant students who came to and began their U.S. schooling in the sixth to eighth grade, and who were continuously enrolled in U.S. schools up through the 12th grade. These college students are non-native speakers of English who are orally fluent but need additional linguistic and academic support before taking college-level courses. 
Goal commitment is the student's planned commitment to completing college and graduating (Tinto, 1975).

Hispanic/Latino/a is a broad ethnic term used to reference persons of Mexican, Spanishspeaking Caribbean, Spanish-speaking Central and South American, and Spanish descent.

In-term persistence is the act of attending and completing in one term a class or classes in which one is enrolled.

International student is a nonimmigrant student who has been extended a student visa (I20) from a specific institution that allows the individual to enter the United States for the sole purpose of pursuing academic coursework. Upon completing their studies, international students must return to their country of origin.

Legal resident is a student who holds an alien registration card that documents his or her legal residency in the United States.

Nontraditional. Definition from the Greenwood Dictionary of Education (2003):

"Individuals who enter or return to university or college beyond the typical age (mid-twenties). The term also applies to ethnic minorities, women with dependent children, underprepared students, and other groups less commonly represented in postsecondary educational institutions” (p. 241).

Persistence is a student's uninterrupted enrollment until completion in a course or program. While persistence can be defined in multiple ways, in this study it is measured as within one complete term.

Retention is continued enrollment from one semester to the next semester until the educational goal is accomplished. 
Term is one semester.

Withdrawal is a student's decision to leave a course, program, or college prior to completion of the course, program or degree.

\section{Significance of the Study}

Community colleges serving ESL students continue to invest time and resources in planning programs to meet the academic needs of language-minority students. As a result of innovative and enhanced teaching approaches, ESL teachers are better prepared methodologically and pedagogically than they were 20 years ago (Cope \& Hannah, 1975; Driscoll, 2007), and instructional resources and support services are improved and increased (Rendón, 2002). Still colleges seek new and different ways to increase the retention rates of language-minority students. Persistence studies have characteristically concentrated on term-to-term persistence and persistence to graduation; but the single most significant step to getting students to the goal of graduation or program completion is getting students to complete the courses in which they are enrolled each semester. As a result, predictors of in-term persistence and variables that contribute to successful in-term persistence are critical to an overall retention program as well as to student success.

During the 2008-2009 academic year, there was an average 10\% rate of in-term withdrawal for the ESL population in this study (ESL/Reading/SLS Department records, AY 2008-2009). Without a stated retention goal, this current retention rate falls short of an ideal $100 \%$ retention rate.

This study suggested a different approach to persistence studies by way of identifying selected variables that predict in-term persistence, and thus contributed a distinct perspective to the body of persistence research. By looking more deeply but for a 
shorter period of time, this study was undertaken to tease out other factors that the institution can control, factors that go beyond demographics and income, and that will increase the term-to-term persistence rate. This study was also conducted to serve as a model for a larger scale study of in-term persistence of language-minority students.

\section{Delimitations of the Study}

The delimitations of this study are:

1. The scope of this research study was limited to students attending one campus of one large community college in south Florida.

2. The population for this study was limited to ESL students enrolled in five levels of ESL courses in one academic term.

\section{Summary}

The main goal of this research study was to investigate factors that predict language-minority students’ in-term persistence to course completion in English-as-asecond-language courses offered at a large community college in south Florida. Persistence theory suggests that community college students' decision to depart is a complex decision that is influenced by a variety of variables to include entry characteristics, student commitment, and academic integration into the institutional environment. Within this context, persistence studies have focused on persistence to graduation or freshman to sophomore year enrollment. If, however, only those students who complete the term and re-enroll will eventually persist to graduation or program completion, then those variables that predict in-term persistence are valuable for predicting overall persistence. If students persist from start to end of term, they are more likely to re-enroll; and if they re-enroll, they are more likely to graduate. 
This dissertation was undertaken to investigate selected factors that predict interm persistence for English-as-a-second-language students enrolled in an English for Academic Purposes Program at a community college. This chapter provided an overview and introduction to the study along with the statement of the problem. In addition, the conceptual framework, research questions and the purpose of the study were also discussed. Chapter II of the study contains a review of the related literature. Chapter III discusses the research methods, design of the survey, data collection, and treatment of the data. In Chapter IV, the results and findings of the study are discussed in narrative form, accompanied by tables and graphics. Finally, Chapter V presents conclusions, recommendations for practice, and recommendations for further study. 


\section{Chapter II}

\section{Literature Review}

The goal of this study was to identify factors that predict in-term persistence for community college ESL students in an EAP program. Attrition studies on second language students attending 4-year colleges and universities have suggested a number of factors that contribute to their persistence (Driscoll, 2007; Hurtado \& Carter, 1996;

Murphy, 2006). Likewise, much research has been done on student persistence from fall to spring or from freshman to sophomore years. However, very few studies have focused on second language students' in-term persistence. Students who persist to complete courses are more likely to re-enroll; students who re-enroll are more likely to graduate. Their low persistence rate is a real concern for colleges, as it is a significant measure of institutional performance as well as of student success.

In Chapter I, a general research question was stated regarding the in-term persistence of ESL community college students: Which selected factors predict in-term persistence for ESL students enrolled in an EAP program in a community college? The following review explored possible answers to this question as they are found in the theoretical literature and empirical studies on community college student persistence.

\section{Persistence Theories}

\section{Tinto's Theory of Student Persistence}

Tinto’s (1975) model of student persistence posits that students come to college with a range of different background characteristics and high school experiences that lead to initial student commitments to the institution and to the goal of graduating from college. Tinto theorized that students enter college with a variety of unique family 
background characteristics, individual attributes and precollege experiences, which influence how the students will perform in college as well as how they will interact with, and integrate into, the college's social and academic systems. Included in background characteristics are family socioeconomic status, parental educational level, and parental expectations. Individual attributes include academic ability, race, and gender; precollege schooling experiences include those high-school elements that define achievement, such as high-school academic achievement and social attainments. Together, these influence the student's interaction with, and integration into, the college's academic and social systems. The greater the student's level of integration in the social and academic systems of the college, the greater will be the student's commitment to the college and to the goal of graduation. These subsequent commitments, along with levels of social and academic integration, are offered by Tinto as having direct, positive influence on persistence. Entry characteristics also influence students' initial commitment to the institution and to the goal of graduation, which in turn, influences the level of students' academic and social integration. Cope and Hannah (1975) concur that a "personal commitment to either an academic or occupational goal is the single most important determinant of persistence in college” (p. 19).

Though foundational to an understanding of persistence theory, research guided by Tinto's model was initially limited in a number of ways. Nearly all of the research using the Tinto model was originally conducted at single suburban, 4-year institutions over relatively short periods of time, to the disregard of students who either transferred or stopped-out (Pascarella \& Terenzini, 1980). However, research using Tinto’s model of student persistence has increased the understanding of why and when students drop out, 
as well as what can be done to encourage student persistence (Cabrera, Nora \&

Castañeda, 1993; Carter, 2006; Halpin, 1990). A key element in Tinto’s theory is the link between student involvement or integration (academic and social) and student persistence. This theory has been challenged for its limited relevance both to community college students and to minority and second language students (Braxton, Sullivan, \& Johnson, 1997; Guiffrida, 2006). Still Tinto’s $(1993,1996)$ stress on the importance of personal commitment to an educational or occupational goal is critical to understanding the persistence of language-minority students.

\section{Bean's Model of Persistence Behavior}

Instead of goal commitment, Bean (1980) stressed the importance of behavioral intentions as predictors of persistence behavior, and his Student Attrition Model hypothesized that student attrition is comparable to the turnover in work organizations. After many years of research on student persistence behavior, Bean (1990) determined that community college attrition is difficult to study because of the heterogeneity of the student body and the differences in students' purposes for attending these schools. He also concluded that withdrawal decisions are complex in part because they develop over time, and each student's decision to leave is based on individual factors. These factors are shaped by a combined process involving attitudes that influence behavioral intents, which in turn is influenced by the student's experience at the institution. Bean and Metzner (1985) concluded that no theoretical model was available to guide attrition research on the nontraditional student enrolled in institutions of higher education, and so they aimed to develop such a model. The form was drawn from existing models of traditional student attrition and retained the three basic elements of background variables, withdrawal as a 
longitudinal process, and identification of a set of academic variables that affect attrition decisions. The substance came from an extensive review of the literature on nontraditional students. The resulting model indicates that decisions to withdraw will be based primarily on four sets of variables: poor academic performance, intent to leave, background and defining variables, and environmental variables.

Persistence and retention studies have identified many predictors used by colleges committed to creating an educational environment where students persist and succeed. Over the past 25 years, persistence studies among college students (Cabrera et al., 1993; Pascarella \& Terenzini, 1980), minority college students (Carter, 2006), community college students (Cofer \& Somers, 2001; Halpin, 1990), and minority community college students (Alfonso, 2006; Laden 2004; Leinbach \& Bailey, 2006) have identified factors that impact persistence and are common to all college students. Studies have also found factors that impact persistence and are unique to certain categories of college students (Hurtado \& Carter, 1996; Johnson, 1997; Liu \& Liu, 1999; Smith, Street, \& Olivarez, 2002). Regardless of the category in which community college students are placed, a common finding is that they attend college to earn a certificate or associate degree, prepare to transfer, enhance their job skills, or improve their English or basic literacy skills (Laden, 2004). As a result of the research among minority community college students, key areas for persistence have been found to be academic preparation, adequate financial aid, and strong support networks in college (Carter, 2006).

Persistence theories establish a premise for providing colleges with contexts from which to launch services and programs designed to engage and retain students to completion. However, while community colleges continue to expend considerable effort 
and resources to sustain student persistence, there is little or no evident change. One identifiable reason is that persistence theories focus either on term-to-term or year-to-year persistence, while significant numbers of non persisters act on their decision to depart during the term. These students are included in the general category of non-completers, and as such, are not differentiated from students who fail to return after completing the term or the year. There is a dearth of data on students who withdraw during the term, which creates a vacuum in the available information that colleges turn to in search of factors that predict students' in-term persistence. A closer examination of variables that impact a student's decision to withdraw during the term, that goes deeper into variables not considered in the term-to-term studies, will give insight into an important component of overall student persistence.

\section{Research on College-Student Persistence}

The research literature is rich with studies and reports conducted by colleges on the retention of students and the improvement of student persistence. As a result of these studies, there is a lengthy list that is constantly growing and changing of known factors that impact persistence and retention.

In an early study, Astin (1972) found that students’ GPAs during the freshman and sophomore years were more closely related to students’ probability of graduation than any other single variable. Later research by Astin (1993) and others (Pascarella \& Terenzini, 1991; Reason, Terenzini, \& Domingo, 2006) also suggest that academic achievement could be the greatest predictor of student persistence and completion of a bachelor's degree. Other factors that should be considered as predictors of persistence include gender, participation in developmental courses, and institutional fit. Tinto (1975) 
found that a higher proportion of men than women were finished college degree programs, and Carter (2006) determined that participation in both language and math remedial courses was consistently and positively associated with persistence in college. Pascarella, Smart, and Ethington (1986) confirms the influence on student persistence/withdrawal behavior of the person-environment fit, and conclude that what happens to a student after he or she enrolls at an institution may be as important to ultimate persistence as the influence of pre-college variables. Bean (1990) reiterates that "institutional fit and loyalty are the specific attitudes towards the institution that closely affect the decision to remain enrolled in school” (p. 165).

As a result of the influence of Tinto's (1993) work with student retention, persistence studies have traditionally focused on social and academic integration as the key factor (Johnson, 1997; Strauss \& Volkwein, 2004). Integration studies have generated their own list of variables that influence or predict academic and social integration. In her study of students attending commuter colleges, Johnson (1997) found that many of the factors that contribute to successful student retention of traditional campus-based college students are also significant for commuter and nontraditional students, and that a sense of community generated by the academic climate and social integration is important to commuter students. In their study with students at a commuter campus, Liu and Liu (1999) also found formal and informal student-faculty relationships to be crucial to student retention. Alternately, Borglum and Kubala (2000) found that commuting students rarely have the time or the interest to involve themselves in any campus activities other than classes, and as a result, the need to commute exerts a negative impact on the social integration of community college students. 
Institutional commitment has surfaced as a credible predictor of college students' intent to persist, and as such, as a strong contributor to actual student persistence (Cabrera et al., 1993; Strauss \& Volkwein, 2004; Tinto, 1987, 1993). Strauss and Volkwein identified multiple individual variables contributing to institutional commitment, and found the most important influences to be the measures of academic integration and growth, followed by the measures of social integration and growth. Strauss and Volkwein (2004) also found, when controlling for all other variables, that first-year students at 2year institutions have slightly higher institutional commitment scores than first-year students at 4-year institutions.

Using Astin’s (1995) theory of input-environment-output (I-E-O), House (1998) investigated the contributions of entering students' characteristics on student satisfaction with college and degree completion. Results indicated that students with higher high school grades, higher self-perception of their academic ability, and greater expectations of graduating with honors were more likely to persist to the completion of a bachelor's degree. Another finding was that students who spend more hours per week studying and doing homework, and who spent fewer hours per week commuting, were more satisfied with the overall quality of the instruction they received and therefore more likely to persist. The results of this study suggest that there are different types of student characteristics as well as environmental variables that result in the outcome of student persistence.

The first year in college is particularly critical to a student's decision to persist. Academic success in the first year is predictive of success in general. First-year-incollege students tend to succeed when they make progress toward fulfilling their personal 
and educational goals. Factors that individually and collectively shape students' development of academic competence in their first year of college framed the research study done by Reason et al. (2006). That study was a part of a national effort to transform how colleges and universities think about, package, and present their first year of college. The study was part of the Foundations of Excellence in the First College Year Project, a 2-year national research and development effort to increase understanding of the multiple, interconnected factors that influence academic success and persistence among first-year college students. Based on data from nearly 6,700 students and 5,000 faculty members on 30, 4-year campuses nationwide, the study sought to identify the individual, organizational, environmental, programmatic, and policy factors that individually and collectively shape first-year students’ academic success. Guided by Astin’s (1993) InputEnvironment-Output approach, the Reason et al. study hypothesis that students come to college with a range of demographic, personal, and academic characteristics and experiences, concurs with Tinto's (1993) background characteristics. These traits shape students' engagement and involvement, and are in turn shaped by the institution's characteristics, practices and policies, and the campus' faculty and culture. Based on their results, Reason et al. (2006) recommended that, among other things, faculty members must be proactive in the use of pedagogical methods that promote active student engagement with their courses' content. Active, engaged students are more likely to persist, and some of the ways in which faculty can engage students is to require them to participate actively in classes; to do multiple rewrites of papers; and to be exposed to diverse peoples, cultures, and ideas. That study suggested that students’ perceived 
support, degree of cognitive and academic engagement, and perceptions of institutional expectations were directly related to students' reported gains in academic competence.

Otero, Rivas,and Rivera (2007) studied demographic and academic variables associated with first-year Hispanic student attrition and persistence at a predominantly Hispanic university located in the Southwestern United States. First-year students who failed one of the sections of the state-mandated college placement test are required to participate in a program designed for at-risk students. There were 311 students initially enrolled in the program at the beginning of the spring 2001 semester. At the end of the semester, 134 students volunteered to participate in this study. The group of volunteers was $98.5 \%$ Hispanic, which mirrored closely the $91.7 \%$ Hispanic make-up of the total student body. Of the 134 questionnaires administered, 28 were eliminated because they contained missing or invalid data, leaving 106 valid questionnaires. Of the 106 students, 73 (69\%) were still enrolled after 1 year. A logit statistical model was used to find which factors likely contributed to student retention or were likely to have affected the decision to leave the institution. Age, marital status, having children, and number of hours of study per week did not predict students' decision to continue in college (statistically nonsignificant). A student's decision to remain in the university was best predicted by social integration. Social integration was measured with a student-center variable - "spending time socializing with friends in the Student Center or other campus areas is important”and showed an $11 \%$ higher likelihood of staying in college. In this study "getting good grades is important to me” was used as a proxy to measure academic motivation. Students who strongly agree that getting good grades is important have a higher probability of continuing in the university. 
Retention and persistence studies have been in place in 4-year and community colleges for many decades and are now a permanent segment of institutional assessment. Many studies have identified factors that influence retention and predict persistence, particularly academic and social integration, and first-year-in-college success. Other predictors include being actively engaged in the classroom, making gains in academic competence, spending fewer hours commuting and more hours studying, experiencing a sense of community on campus, and having either a formal or informal relationship with faculty. However, these characteristics have not been studied for ESL students' in-term persistence in an EAP program. These findings suggest the possibility of additional predictors that were not identified in the studies cited, as well as the veracity of Bean's (1990) conclusion that withdrawal decisions are complex, develop over time, and are based on individual factors. One of the goals of this research is to add to the list of known predictors, whether individual or communal, of in-term persistence of ESL students in an EAP program.

\section{Research on the Persistence of Community College Students}

Retention research in the 4-year college setting has traditionally assumed that students intend to achieve a degree, and that when a student leaves school, either the college or the student has failed. In an effort to demonstrate that such assumptions do not apply when examining retention among 2-year college students, Brookdale Community College began administering an Entering Student Survey to new students in the fall of 1988 to gather information about their academic goals and expectations and compare survey results with subsequent retention behavior. Daniels (1990), reporting on the findings, pointed out that students who indicated an intention to graduate had higher 
persistence rates than those not intending to graduate, and that student success must be measured in light of students' goals and intentions. Bonham and Luckie (1993) suggested that students who intend to take only a few classes and stop attending when they accomplish their educational goals, should be considered as "optouts," and only persons who failed to accomplish their educational goal and have no definite plans to accomplish it later should be considered as dropouts.

The typical profile of the community college student is one who has a full- or part-time job, lives off-campus, and is taking classes on a part-time basis (AACC, 2009). This makes persistence a particular challenge for the community college student. Despite the continually increasing efforts of colleges to tackle attrition in varying ways, only 38.7\% of students in 2-year institutions will graduate (Tinto, 1993). Borglun and Kubala (2000) applied Tinto's model to 2-year institutions in a study of second semester, degreeseeking community college students who completed a survey regarding their satisfaction with the academic and social climate of the community college. The population for that study consisted of all students enrolled in courses at the West, East, and Osceola campuses of Valencia Community College in Orlando, Florida, in the spring semester of 1998. The study was conducted using a cluster sample of required and elective courses across the three campuses. Participants were students in their second semester at the college and were enrolled in 9-15 credit hours, and working toward an associate of arts or associate of science degree. Of 2,115 students surveyed, 462 (38\%) met the criteria of being second-semester degree-seeking students who signed the informed consent form. The survey questions were broken down into four categories according to Tinto's model: (a) pre entry attributes, (b) goals and intentions, (c) social integration, and (d) academic 
integration. Results revealed that there was no correlation between academic or social integration and withdrawal rates. This could be due to the fact that second-semester students have passed through the "weeding out" process between first and second semesters, and are more likely to have decided on their goals in relationship to their enrollment in community college. These students' responses indicated that they were satisfied with the quality of instruction, the relationship with their instructors, had no opinion about extracurricular activities on campus, and did not want to engage in campus activities or spend more time on campus. These students were goal-oriented, were on campus to attend their classes, and desired to complete their associate of arts or science degree within a specified number of semesters.

Noteworthy is the implication that community colleges need not spend time, money, or effort trying to find ways to encourage students to stay on campus (Borglum \& Kubala, 2000.) Other findings in that study are that the background skills with which students entered the community college had a significant relationship with the number of withdrawals. Students with higher mean scores on the College Placement Test (CPT) required of all Valencia students, had no withdrawals, whereas students with lower mean CPT scores had one or more withdrawals. This may indicate that many students attending community college are underprepared, and when CPT scores indicate a weak academic background and the need for college preparatory classes, these students become discouraged and withdraw.

Driscoll (2007) calls attention to the critical importance of students' first college semester, which becomes the key in determining their subsequent educational track. With 6 years of data from the California Community Colleges Chancellor's Office, this report 
provided evidence that the first year-and even the first semester—is pivotal to students' academic success. More than half of the 17-20-year-old students participating in this study entered community college with the primary goal of transferring to a 4-year college to earn a bachelor's degree. Students who had an initial positive academic experience in college were more likely to persist toward their goals. Still, $25.7 \%$ of these students who entered college aspiring to transfer, left school after the first semester, and 33.6\% of them persisted but lowered their educational expectations and no longer desired to transfer. One possible explanation for this change among many continuing students may be that they did not fully appreciate the academic challenges they would face. They reported underestimating the time and effort required to achieve their educational expectations, and over-estimating their preparedness for college-level work. As a result, they performed poorly in their classes and became discouraged and lowered their academic expectations.

Bers and Smith (1991) studied a midsize suburban community college in the Midwest, using a random sample of students who completed the Current Student Survey. Students were randomly selected for participation from all those enrolled in the fall 1988 term. The questionnaires were administered in classes in early October to 1,142 students, and 420 of those students provided social security numbers, enabling researchers to draw additional data from the college's student information system. Analysis of the results were aimed at answering the question of whether academic and social integration differentiate persisters and non persisters, and if a factor such as student education objective was influential in students' level of integration at the institution. Background characteristics such as gender, age, employment, ethnicity, and program were included as 
covariates in the discriminant analysis. Results showed that among the predictors, employment status contributes most to the discriminant function, and the more hours students were employed, the less likely they were to persist. However, students not employed were less likely to persist than those who were employed part-time. Students' educational objective also contributed substantially to the discriminant function. This indicated that students taking courses for personal improvement or job-related needs were less likely to persist than students pursuing a degree or planning to transfer. Overall results of the discriminant analysis indicated that while academic and social integration contribute to the differentiation of persisters from non persisters, educational objective and employment status made a more substantial contribution.

At community colleges, attendance patterns reveal a substantial amount of stopout behavior, and persistence from one semester to the next during the academic year averages about 50\% (National Center for Education Statistics [NCES], 2008). Some students will complete a term before leaving the institution for one or more terms, while other non persisters have a pattern of withdrawing during a term to return either in the next or a subsequent term. Because of the high percentage of non persisters in contiguous semesters, community colleges typically focus their efforts on a semester-to-semester retention. These efforts disregard the pattern of withdrawals that occur during the term. As useful as it is to identify those variables that contribute to term-to-term persistence, it is also useful to identify those variables that differentiate in-term persisters from non persisters.

Pascarella, Wolniak, and Pierson (2003) studied 285 students attending five community colleges to identify the institutional and college experience variables 
influencing end-of-first-year educational degree plans. They demonstrated considerable variation among community college environments with respect to impact on student change and growth. Also, they found considerable complexity in the impact of institutional and college experience variables on the overall degree plans of community college students. The study looked at a substantial number of academic and nonacademic experiences that had statistically non significant general effects on end-of-first-year degree plans, but had statistically conditional effects for different sub groupings of students based on sex, race, and level of precollege degree plans.

The purpose of Barnett's (2007) research was to examine the extent to which urban community college students' validation contributed to their sense of integration in college, and whether this contributed to their intent to persist in college. Barnett used Rendón's (2002) concept of validation to mean "interactions with students initiated by faculty and others in the campus community that engender feelings of self-worth and a belief in the ability to succeed in the college environment” (p. 4). The study tested five research hypotheses and two sub hypotheses about whether or not higher levels of faculty validation predict a stronger sense of integration in the college or a stronger intent to persist in college among urban community college students. Four sub constructs of faculty validation emerged through principal components analysis: students known and valued, good instruction, appreciation for diversity, and mentoring. After controlling for students' age, gender, race, part/full time status, and college GPA, faculty validation was found to strongly predict students' sense of integration and modestly predicted students' intent to persist. The effect of faculty validation on intent to persist was indirect; it was mediated through students' sense of integration. Scoggin and Styron (2006) also showed 
that the primary factor in student withdrawal from community college was personal reasons, with other leading causes being financial reasons and work. This study pointed out that retention activity should involve holding the students accountable for their attendance at school. Not attending classes for personal or other reasons can seriously interfere with learning and could lead to a reduction in intent to persist.

Cofer and Somers (2001) examined the effects of background, achievement, college experience, and price and accumulated debt on within-year persistence at 2-year colleges from 1993 to 1996. The effect of debt on 2-year college students presents an interesting picture, but those who are motivated to persist are also willing to assume large amounts of debt to meet their goal. Rickinson and Rutherford (1995) identified three main categories for reasons given by students who withdrew from college in their first term: (a) feeling that they were not prepared academically; (b) feeling that they are not prepared emotionally for the demands of school work and college life; (c) personal welfare problems, such as family and financial responsibilities. Hoyt (1999) found that dropout rates are higher among students who work full-time and among students from lower socioeconomic levels.

Finally, Smith et al. (2002) found that the time of a student's registration also exerts influence on community college students' persistence from the fall term to the spring term, more so for new students than for returning students. Findings of the study suggest that late registration practices seem to be detrimental to students in terms of academic success, and seem to hinder retention and student persistence. A summary of findings from studies on predictors of persistence for community college students is presented in Figure 2. 


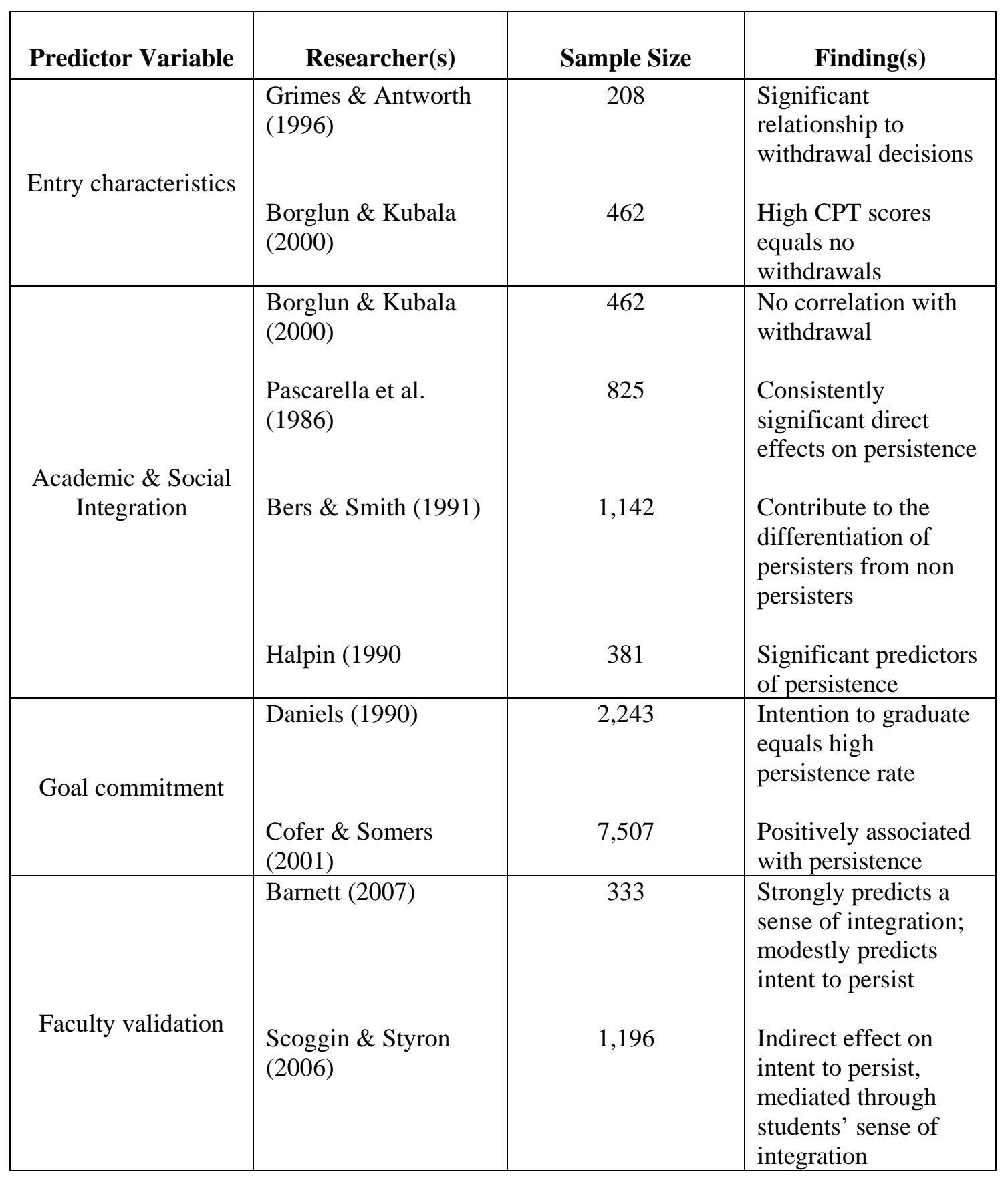

Figure 2. Summary of studies predicting persistence for community college students. 
As found in these studies, the community college student's persistence is influenced by a number and variety of factors, to include student goals and intentions, background skills and preparation, precollege degree plans, specialized support services, financial ability, time of registration, and faculty validation. However, ESL students form a distinctive segment of the community college student population for whom predictors of student persistence are less valid because of the complications of English language competence.

\section{Persistence Among Nontraditional Community College Students}

Using an expanded definition of the term nontraditional to include background characteristics or risk factors means that a significant majority of community college students can be considered nontraditional. Community colleges enroll almost one half of all undergraduates in the United States each fall, and most students in community college fit one or more of the descriptors of nontraditional (NCES, 2005). Approximately one half of all African American, Native American, and Hispanic college students are enrolled at a community college (AACC, 2009). Almost 46\% of first-time entrants into community colleges enroll part-time, $35 \%$ of first-time entrants in community colleges work full-time (NCES, 2005), and the average age of the community college student is 29 (AACC, 2009). The term nontraditional has often been used to define student characteristics including ethnicity (Kim, 2002). In her discussion of nontraditional students in community colleges, Rendón $(1994,2000)$ considers first-generation as one of the three defining characteristics. A third approach to defining nontraditional focuses on factors that may increase students' risk of attrition (NCES, 2008). Three-fourths of 
students in 2-year colleges have at least one of the following seven factors identified by NCES as putting students at risk and being more nontraditional:

1. Not enrolling within the same year of completion of high school,

2. Attending part time,

3. Being financially independent of parents,

4. Working full time,

5. Having dependents other than a spouse,

6. Being a single parent, or

7. Not having a high school diploma.

Kim (2002) found that nontraditional students in 2-year institutions are more likely to have two or more risk factors, and $22.9 \%$ have four or more. Retention of nontraditional students then becomes a key issue for community colleges, and Rendón $(1995,2000)$ suggests that institutions should focus on two critical phases for students: making the transition to college and making academic and social connections in college. Because nontraditional students are more likely to be unfamiliar with the college environment, they feel as though they are living between two worlds. They are breaking away from one world but not yet connected to the other. To prevent this transition from becoming a barrier to academic success and student persistence, Rendón (1995) suggested that community colleges should "keep the culturally diverse learner at the center of restructuring, creating conditions for optimal learning, diversifying faculty and staff, and designating transfer as a high institutional priority” (p. 79).

Jenkins (2007) reported seven strategies found to differentiate high-impact from low-impact Florida community colleges. The colleges were ranked according to the size 
of the estimated effect each college had on the probability that entering minority students would complete, transfer, or persist within 3 years. These rankings were used to select six colleges for field research—-three that had relatively high impacts on the chances that their minority students would succeed and three that had low impacts. Using transcriptlevel data on over 150,000 students, Jenkins estimated the effect of targeted support for minority students on the graduation, transfer, and persistence rates of minority students at the 28 Florida community colleges as a proxy for institutional effectiveness. The findings indicate that where there is targeted support for minority students, there is the clearest difference between high and low-impact colleges. Minority community college students are more likely to succeed at colleges where they are made to feel welcome and where there are support services and programs specifically designed for them.

For racially and ethnically underrepresented minority students, knowledge of the American system of higher education is often limited, and aggressively seeking information and interaction with faculty on campus can be at odds with their native culture. Miller, Pope, and Steinman (2005) found the demographic characteristics and lifestyles of contemporary community college students to have changed significantly from even a decade ago; students are more ethnically and racially diverse, younger, and have more career-directed expectations of higher education. As a result, the community college student now presents different challenges, such as instruction in English-as-asecond-language, providing special mentoring to match the diversity of students, and gaining an accurate understanding of how these students define success relevant to their background. If the unique characteristics of these students are not addressed by the 
college faculty and staff, they will in themselves create barriers to academic success and student persistence for the contemporary community college student.

Working outside the home remains one of the unchanging characteristics of community college students, registered at an even higher rate in the nontraditional community college student population. Miller et al. (2005) reported on a study that sought to provide clarity on the challenges and stressors with which community college students are confronted. Of the 300 students who participated in the study, $14 \%$ of them identified themselves as representing more than one minority background, $75 \%$ of them reported working outside the home, with 54\% of them working between 11 and 35 hours per week. Achieving academic success was noted as the most challenging factor for the participants of this study, and the definitions of academic success were as varied as the students were diverse. However it was defined, there was a clear perception by these students that the academic process is particularly daunting. This finding is consistent with previous research (Carter, 2006; Grimes \& Antworth, 1996; Scoggin \& Styron, 2006) on the characteristics of community college students that impede their academic success.

Carter (2006) found that for White college students, having a declared major was consistently and positively associated with persistence. However, for African-Americans, several academic majors were negatively associated with persistence. Grades in college were positively associated with persistence, as was taking remedial courses in both language and math. Finally, there were differences in the effects of student financial aid across racial or ethnic groups in 2000; high income students were more likely to persist in all three racial/ethnic groups (White, Hispanic, and African American). For Hispanics, 
receiving financial aid packages with work-study, substantially improved the odds of persistence.

Another factor that showed significant impact on nontraditional student persistence is faculty interaction and validation. Chang's (2005) study on faculty-student interaction on 2-year college campuses surveyed a representative sample of 5,000 students at the nine campuses of the Los Angeles Community College District during the spring of 2001. In addition to 730 White students in the sample, the other students were African-American (779), American Indian (112), Asian American/Pacific Islander (797), and Latino (2830) students. Results revealed generally low levels of faculty-student interaction on community college campuses. Interactions with Asian American/Pacific Islander and Latino students were especially low. The findings of the study were consistent with past research (Braxton, Hirachy, \& McClendon, 2004; Rendón, 2002) that has shown faculty-student interaction to positively influence a number of student outcomes and be of particular benefit to the academic achievement and persistence of students of color.

More than 30\% of all community college students in the United States are minorities, and $41 \%$ of the students attending community colleges in Florida are minorities. The nontraditional designator is considerably broader than minority, and consequently, it is of greater value to look at specific subpopulations and focus on characteristics that all members of a group share, such as employment status, firstgeneration status, or minority status. Numerous research studies have disclosed variables that help or hinder persistence in nontraditional community college students, such as parttime attendance and full-time employment, first generation in college students, limited 
knowledge of the American higher education system, and lack of faculty interaction and validation. However, there remains a significant dearth of studies that focus specifically on language-minority students and the variables that predict their persistence in community college. The goal of this study is to add to this body of research by identifying variables that predict in-term persistence for ESL students in a community college EAP program.

\section{Persistence Among Language-Minority Community College Students}

Stage (1989) calls attention to the fact that while commitment is central to Tinto's (1993) theory, it falls short of providing an understanding of students' motivational orientations to such commitments. This limitation is of particular significance when using Tinto's theory to analyze minority student academic achievement and persistence. The research suggests that for language-minority students, motivation for attending and succeeding in college may differ greatly from their White American peers (Guiffrida, 2006; Rendón, 2002; Stage, 1989). Their goals, intentions, and motivation for academic success is determined by individual, yet characteristic, factors particular to this subgroup of minority students. Cross's (1976) caution is noteworthy, that "educational opportunity means more than the right to meet minimal standards; it means the right to develop one's talents to maximum effectiveness” (p. 3). In this sense, community colleges are called on to provide language-minority students with more than access. They are called on to identify, assess, and place ESL students at appropriate entry levels to facilitate equal access to educational opportunities, and then to provide that unique academic experience that will influence the language-minority student to persist and succeed. 
Mery (1995) looked at course completion for credit and noncredit ESL students in a study at the City College of San Francisco. Some of the findings of that study indicated that credit ESL students had an overall course completion rate of $83.2 \%$ compared to the overall course completion rate of $80.5 \%$. Of specific relevance is the finding that new credit ESL students who were tested and placed into a particular course level, had higher course completion rates than continuing credit ESL students who were promoted from one course level to the next. Also, new foreign students with F1 visas had the highest overall credit ESL course completion rate of $88.6 \%$, and new credit ESL students from U.S. high schools had the lowest overall course completion rate at $66.46 \%$.

The specific interest of research done by Hagedorn et al. (2007) was the role and effect of the level of representation of Latino community college students on their academic success. The relationship between the level of representation of Latinos and the levels of academic success were analyzed in conjunction with other variables, such as the level of representation of Latino faculty on campus, academic integration, English ability and aspiration. The study applied the concept of critical mass to the measure of success of Latino community college students, and found that critical mass is indeed an important predictor for student success in urban, Latino community college students. While there was not a strong link between English ability and academic integration with academic success, student aspiration and academic attitude were found to be significant predictors for success.

Escobedo (2007) reported on a pilot study done under a U.S. Department of Education Hispanic Serving Institution Title V grant at a 2-year urban community college in the Southwest. The study intended to affect change in developmental student services, 
to improve persistence and retention rates, and to institutionalize effective processes

learned. Results demonstrated that Seidman’s (2005) formula for “high touch”-retention = early identification + early + intensive + continuous intervention-effectively contributed to retaining students. One of the most successful aspects of the Student Retention Specialist Pilot was the ongoing communication between the student retention specialists and the faculty. Internal institutional research indicated that a variety of "high touch” student contacts, that is, early alert postcards, classroom presentations, and completion of an education plan, showed positive effects on student persistence.

The concept of "high touch” has impacted other successful programs, designed to retain language-minority students. In 1981, the Puente Project was initiated as a Latinospecific program at Chabot College in Hayward, California, and is now in place at more than 38 California 2-year colleges. The original emphasis on Community College Puente was to enlarge the pool of Latino students who transferred from 2- to 4-year colleges and universities in California. The success of the program is indicated by over $90 \%$ of transfer students who believed that Puente prepared them for university-level reading and writing, and the finding that $95 \%$ of all Puente students indicated that they would recommend the program to their friends. Rendón’s (2002) qualitative study gave particular emphasis to validation in a Puente English classroom in the following ways (among others):

1. Affirming the real possibility that students can be successful college students.

2. Affirming the students' personal voice, by actively reaching out to students to offer academic assistance. 
3. Affirming the culture of the students, by stressing academic strengths to build self-confidence.

4. Affirming the value of personal experience as a reservoir of knowledge that can be used in the classroom.

5. Creating a familia learning atmosphere, by validating the students’ personal journeys to discover meaning and purpose.

6. Affirming students as individuals, not just students.

A key finding of the study is that validation helps students to gain confidence in their academic ability and to know that their newly acquired skills can transfer to other classes. It is well documented that even when Latino students enroll in college, their retention rates are very poor (Rendón et al., 2000). Getting into college is no guarantee that Latino and other minority students will stay in college; it is therefore important that community colleges wishing to promote access and retention of minority students give careful attention to active and sustained intervention in order to retain these students.

Kangas and Budros (1993) conducted a study at Evergreen Valley College (EVC) and San Jose City College (SJCC) to determine the number and percentage of ESL students who began at each level and who reached a position to take college-level courses, to graduate, and to transfer. All new ESL students without previous college experience who began in fall 1988 were tracked over 4 academic years to determine how many completed the ESL prerequisites to take college-level courses. Findings are that of the 456 students who began at the various levels, only 15\% completed English 1A (college-level English composition) within 4 years. This low percentage of completion of college-level English composition belies academic success by any measure for ESL 
students. However, the findings of this study do not include either term-to-term persistence rates or in-term persistence rates of the ESL students included in the study. In his presentation at a conference sponsored by the Wisconsin Center for the Advancement of Postsecondary Education, Tinto (2002) offered five conditions that stand out as supportive of persistence: expectation of success; effective advising; academic, social, and personal support; involvement as valued members of the institution; and fostered learning, which sees active involvement in learning as increasing the likelihood that students will stay and graduate. Hurtado and Carter (1996) examined a sense of belonging as an alternative approach to the idea of "integration" on college campuses in order to understand how Latino students view their membership in the college community. Results showed that specific forms of campus involvements are more likely to significantly enhance students' sense of belonging with the overall community, but these are not always the forms of involvement typically used by researchers. Perhaps the most important finding of the study is that early experiences are key determinants of Latino students' sense of belonging in later years. Hurtado and Carter concluded that successful integration of Latino students in colleges and universities is directly dependent upon students having clear information about the campus from peers and faculty.

Community colleges serving under prepared students are challenged to provide the resources, services, and interventions necessary to facilitate students’ academic success. Community college students are more likely to "reflect the factors that put students most at risk of not attaining a degree. Those factors include delayed entry, parttime enrollment, full-time employment, financial independence, single parenthood, family dependents, and under-preparation for college” (Community College Survey of 
Student Engagement, 2002, p. 1). When the community college student is also a language minority student, the challenge to persist in college is affected by additional factors, such as cultural adjustments, first generation in U.S. college, and English language competency. Community colleges have implemented many of the research findings found to contribute to language minority students’ persistence: “high touch” (Escobedo, 2007), critical mass (Hagedorn et al., 2007), faculty validation (Barnett, 2007), and clear information (Carter, 2006). However, available statistics measure student persistence from fall-to-fall (AACTE, 2009), while research studies look at within-year or graduation as a measure of student persistence. Mery (1995) singularly examined overall course completion rates for credit and noncredit ESL students, to find that foreign students had the highest overall ESL course completion rate. There is a dearth of studies in the available literature that examined predictors of ESL students' in-term persistence, and as a result, this study seeks to examine factors that influence the decision of ESL students to persist from the start to the end of the term. Predicting in-term persistence provides valuable opportunities for immediate intervention that are not available in graduation studies.

A summary of the results from studies on predictors of minority students' persistence in community colleges is presented in Figure 3. 


\begin{tabular}{|c|c|c|c|}
\hline Predictor Variable & Researcher(s) & Sample Size & Finding(s) \\
\hline $\begin{array}{l}\text { Academic \& Social } \\
\text { Integration }\end{array}$ & $\begin{array}{l}\text { Hagedorn et al. } \\
\text { (2007) }\end{array}$ & $\begin{array}{c}5,011 \\
\text { (Latino, Chicano, or } \\
\text { Hispanic students) }\end{array}$ & $\begin{array}{l}\text { The relationship } \\
\text { between Latino } \\
\text { faculty and student } \\
\text { success is significant }\end{array}$ \\
\hline Goal commitment & $\begin{array}{l}\text { Kangas \& Budros } \\
\text { (1993) } \\
\text { Mery (1995) } \\
\text { Otero et al. (2007) }\end{array}$ & $\begin{array}{c}456 \\
\text { (ESL students) } \\
\text { 3,993 } \\
\text { (Credit ESL students) } \\
\\
\\
134 \\
\text { (98.5\% Hispanic at- } \\
\text { risk students) }\end{array}$ & $\begin{array}{l}\text { The higher the level } \\
\text { at which an ESL } \\
\text { student starts, the } \\
\text { more likely he/she is } \\
\text { to reach transfer } \\
\text { level English } \\
\text { Credit ESL students } \\
\text { had a higher course } \\
\text { completion rate } \\
\text { compared to college- } \\
\text { wide course } \\
\text { completion rates } \\
\text { Planning to graduate } \\
\text { contribute greatly to } \\
\text { students' persistence } \\
\text { at the institution }\end{array}$ \\
\hline Faculty validation & Otero et al. (2007) & $\begin{array}{c}134 \\
\text { (98.5\% Hispanic at- } \\
\text { risk students) }\end{array}$ & $\begin{array}{l}\text { Student-faculty } \\
\text { interaction does not } \\
\text { affect the retention } \\
\text { rate among these } \\
\text { students }\end{array}$ \\
\hline $\begin{array}{l}\text { Special support } \\
\text { service(s) } \\
\text { ("high touch”) }\end{array}$ & Escobedo (2007 & $\begin{array}{c}2,822 \\
\text { (developmental } \\
\text { students at an HIS) }\end{array}$ & $\begin{array}{l}\text { Students with at least } \\
\text { one contact with } \\
\text { Student Retention } \\
\text { Specialist persisted } \\
\text { at substantially } \\
\text { higher rates }\end{array}$ \\
\hline
\end{tabular}

Figure 3. Summary of studies predicting persistence for minority community college students. 


\section{Summary}

This review of the literature has shown that community college students share familiar entry characteristics, goal commitments, and integration challenges in pursuit of the common outcome of persistence to academic success. Tinto (1993), Bean (1990) and Pascarella et al. (2003) propose attrition/retention models that have been used over and again to predict community college students’ persistence. Characteristics of race/ethnicity, gender, academic ability, and parental education level; commitment variables like reasons for attending college, hours of study and hours of employment, and educational level aspiration; and integration indicators like attitudes and behavioral intents, participation in campus activities, and commitment to the institution and to graduation, all contribute to students' decisions to stay or depart. Throughout this review, one common weakness has surfaced in both persistence theories and persistence studies: there has been no specific focus given to students’ in-term departure. Persistence studies have been done with populations that were local, national, large, small, urban and suburban. Consistently, all of these studies have focused on term-to-term persistence, year-to-year persistence, program completion persistence, or persistence to graduation. Yet the most basic construct of start to end-of-term persistence has been ignored, while institutions continue to struggle with student retention. It is precisely this shortcoming in the persistence literature that has created the basis for this study to investigate the factors that predict language-minority community college students' in-term persistence to course completion in EAP courses. Such predictors will enable community colleges serving language-minority populations to design valuable interventions for students' persistence and academic success. While term-to-term persistence analyses include these students, 
this study goes deeper than those prior studies and is more specific in looking at an ESL population and variables specifically identified as relevant to this group. 


\section{Chapter III}

\section{Method}

This chapter reports how the data was collected and analyzed to find possible answers to the question: What predicts the in-term persistence of community college English-as-a-second-language students? The research design and study participants are discussed and described. Sections detailing the instruments and procedures that were used, as well as the data analysis follow.

\section{Research Design}

A sequential mixed-method research design was used to analyze data collected from students and from preexisting college records. Mixed method is defined by Tashakkori and Creswell (2007) as one in which the researcher "collects and analyzes data, integrates the findings, and draws inference using both qualitative and quantitative approaches and methods in a single study” (p. 3). Data were collected in two phases: Phase 1 consisted of self-reported data collected from the student survey and data from existing college records; Phase 2 consisted of data collected from funnel-sequenced interviews (Tashakkori \& Teddlie, 2009) with a matching cohort of students who withdrew during the term and who remained in attendance to the completion of the term.

\section{The Research Setting}

The population for this study was comprised of ESL students who were enrolled in English for Academic Purposes (EAP) courses at the Central Campus of Broward College (BC, formerly Broward Community College). Students were enrolled in one, two, or three courses of the second through the sixth levels of EAP courses. This 
purposive sample was best suited to this study because these ESL students are representative of the community college ESL student in age, level, and course load.

Broward College is one of 28 community colleges in the Florida Community College System and serves the Broward County community in Southeast Florida. It was a suitable setting for this study because of the diversity of the ESL student population, which represents dozens of different primary languages from almost as many different non-English speaking countries. As one group, this ESL student population displays variation on the phenomenon of second language students, while each subgroup or primary language remains fairly homogeneous. This makes it easily possible, if desired, to compare subgroups against one or more key criteria.

Broward College opened its doors to the first class of students in 1960. In 1963 the institution established a permanent campus in Davie (Hugh Adams Central Campus); in 1970 it established a second campus in Hollywood (Judson A. Samuels South Campus); and in 1972 it established a third campus in Coconut Creek (North Campus). In addition to three main campuses, BC has several sites in Broward County: The Willis Holcombe Center (WHC) where the administrative offices are also located in downtown Fort Lauderdale, the Pines Center in Pembroke Pines, the Weston Center in Weston, the Miramar Center in Miramar, and Tigertail Lake Center in Dania Beach. Central Campus is the flagship and largest of BC's campuses, enrolling over 35,000 students in the 20072008 academic year. The EAP courses are offered at all campuses each term, dependent upon enrollment. The study was conducted at Central Campus because it traditionally enrolls the largest number of ESL students registered at Broward College each term. 
Broward College is typical of community colleges in that it serves a diverse student population. However, the racial, ethnic, and language diversity of the BC student body is deeper and richer than most community colleges in the nation. Southeast Florida has long been the gateway of choice to the U.S. for immigrants from Central and South America and the Caribbean. Immigrants to Florida from Asia and the Middle Eastern countries have increased substantially since the 2000 Census (Shin \& Bruno, 2003)). One indication of this influx of immigrants to Florida is documented by the U.S. Department of Commerce in the number of non-English-speakers at home. Whereas $17.9 \%$ of the general population in the U.S. speaks a language other than English at home, more than 23.1\% of the population of Florida speaks a language other than English at home.

The mission statement of Broward College asserts that it aims "to provide high quality educational programs that are affordable and accessible to a diverse community of learners ... through its commitment to student achievement, lifelong learning, academic excellence, and the use of current technology" (Broward College, 2008). The college fulfills its mission to its diverse language-minority population in several ways. It serves as an entry point for those students planning to pursue a college or university degree. It also offers continuing education courses and workforce development opportunities for those students wishing to enhance or develop skills for a specific purpose. Most importantly for language-minority students, the college provides college preparatory EAP courses designed to provide students with the level of English competency that is necessary to perform academically at the college level.

Broward College offers a comprehensive English language program for nonnative speakers of English that is designed primarily to prepare students to engage in college- 
level work with competence and confidence. Over the past 5 academic years (20022007) BC has enrolled an average of 850 students in EAP courses each year. EAP courses are delivered in three separate skills areas: grammar-writing, listening-speaking, and reading comprehension. All entering ESL students are tested to determine their level of proficiency. The placement instrument currently used at the college is a combination of the Level of English Proficiency (LOEP) test and a writing sample. Courses offered in the first four levels of the program are precollege and not transferable; levels five and six are college-credit bearing courses, and may transfer as elective credits. All EAP courses count towards financial aid, students' course load, and college GPA. These courses are sequential, depending on the student's initial placement level. Upon completion of the sequence, students are required to take the College Placement Test (CPT) to document both grammatical and reading readiness for college-level work.

\section{Phase 1}

Phase 1 was used to collect and analyze self-reported data on a questionnaire describing students' pre-enrollment characteristics, employment characteristics, campus integration characteristics, and initial goal commitments. The questionnaire was administered in the classes of the participating students to achieve the highest response rate possible; however, each student completed only one questionnaire.

\section{Participants}

The participants in Phase 1 of the study were students enrolled in levels two through six of the EAP courses. Students from 11 classes $(n=233)$ were invited to participate in the study; a minimum number of 150 students were expected to participate in the study, and a total number of 208 students did participate. These students were 
registered for one, two, or three courses of grammar/writing, reading, and listening/speaking, and each student completed only one questionnaire. Some participants were enrolled at college for the first time, while others were continuing from the previous term. Some students were also returning from having stopped out for a term or two. Participants also varied in country of birth and native language. This purposive sample shared the common characteristic of learning English-as-a-second-language, and consequently facilitated a better exploration of ESL students' persistence from start to end of term. Table 1 presents sample demographic characteristics of the study participants.

Table 1

Sample of ESL Demographic Information-Broward College Central Campus

Characteristic Percent

Gender

Males

Females

Age

Under 18

$18-24$

25-41

$41+$

Racial/Ethnic Origin

American Indian or Alaskan Native
34.1

65.99

0.78

31.64

48.48

19.10

0.23

(table continues) 
Table 1 (continued)

Characteristic

Asian/Pacific Islander

White non-Hispanic

Black non-Hispanic

Hispanic

Unreported
Percent

4.94

22.49

9.50

60.50

2.34

Note. Data are from the calendar year 2008, winter, fall, and summer terms.

\section{Data Collection}

Data were collected from three sources: (a) the Community College ESL Student Questionnaire (CCSEQ), (b) semi-structured interviews, and (c) college records. Each source alone provided limited or incomplete information on the research topic, while the use of multiple sources provided richer data as well as allowed for qualitative crossvalidation (Oliver-Hoyo \& Allen, 2006, p. 43). Triangulation was used to search for convergence among these three different sources of data for themes or categories that were relevant to the study (Creswell \& Plano Clark, 2007).

The questionnaire was designed by the researcher to collect data for this study and is constructed in two parts: the first part asks closed-ended questions to gather demographic and background data; the second part of the questionnaire uses Likert-type scaled items to gather data on students' perceptions. The CCSEQ (see Appendix B) was piloted with a level four ESL class that gave feedback on the layout of the questionnaire, the clarity of the items, the vocabulary, and the total length of the questionnaire. It was also reviewed by two ESL instructors and two peer administrators. The students were 
mainly concerned with the clarity of the items (i.e., does an appointment with my instructor count as a visit to an advisor?). Comments from the instructors addressed the level of vocabulary and the length of the questionnaire, while suggestions from administrators focused on the layout of the items to facilitate the analysis of the data collected. Dr. Abbas Tashakkori provided expert consultation for all aspects of the construction of the questionnaire. The comments and suggestions received were appropriated in the final version of the questionnaire. Some of the changes included the following: (a) the original layout of the questionnaire was changed to add a blank line and visual separation between each item and remove the numbers. (b) Vocabulary was revised for clarification, for example, “counselor” was changed on one item to "advisor” and on another item to "success specialist." (c) Some items were revised to request more information. For example, the original question, “Do you have a job” gave only two response options, “yes” or “no.” This item was revised to add two more options, “full time” and "part time." (d) The last item of the questionnaire asked for information on the student's current immigration or residency status, giving six options from which to choose. It was revised to eliminate the choice of "other.” The questionnaire took an average of 30 minutes to complete.

The items included in the CCESQ are based on the community college minority student persistence literature, and are consistent with other survey instruments currently in use with community college students (i.e., Community College Student Experiences Questionnaire, CCSSE). The CCESQ includes items that provide demographic information, as well as students' goal commitment and integration. Information on goal commitment is obtained through questions in the following areas: time spent in 
preparation for classes, time spent working, reasons for attending college now, and educational aspirations. Items pertaining to integration include participation in campus activities, contact with faculty outside of the classroom, use of college support services, use of the English language, and perception of validation and belonging. Demographic items include age, gender, country of birth, native language, racial/ethnic identification, location of high school completed, parental college education, length of residence in the U.S., and immigration status.

Basic entry characteristics data (i.e., admission placement, number of terms enrolled, and college GPA) were collected during the term from college records for the students participating in the study. Demographic information and data on goal commitment and integration were collected from the questionnaire.

Students were asked to participate in the study as per the established informed consent guidelines at Florida International University and Broward College. Participation in the survey was voluntary, and participating students did not receive any compensation or extra credit for completing the questionnaire.

\section{Variables and Measurement}

The literature on student persistence indicates that entry characteristics, goal commitment, and integration are the primary influences on students' decision to stay or to withdraw (Bean, 1990; Pascarella et al., 1986; Tinto, 1993), and these were the categories of variables in this study. Entry characteristics influence students' motivation for enrolling in college, while goal commitment and integration directly impact persistence. Entry characteristics refer to such aspects as family background and individual attributes. Goal commitment is indicated by academic load (credits per term), reasons for attending 
college, and level of education aspiration. Integration is represented by such variables as participation in campus activities, making friends on campus, interaction with faculty outside of the classroom, and use of institutional support services. Perception of belonging and perception of validation were measured by Likert-type scaled items. Validation is defined by Rendón (1994) as “an enabling, confirming and supportive process initiated by in- and out-of-class agents that fosters academic and interpersonal development” (p. 44). Perception of validation was discovered by students' responses to instructors remembering their names, giving prompt feedback to their performance, understanding that they come from different backgrounds, and feeling like their personal and family history was valued in class. Estimates of reliability for the scales are provided in the dissertation. Table 2 presents the variables, their categories, and the sources from which they are drawn for the study population.

Table 2

Phase 1 Variables, Sources, and Categories

\begin{tabular}{|c|c|c|c|}
\hline & Variable & Source & Category \\
\hline 1. & Gender & CCSEQ & Entry characteristics \\
\hline 2. & Race/Ethnicity & CCSEQ & Entry characteristics \\
\hline 3. & College placement & College records & Entry characteristics \\
\hline 4. & High school experience & College records & Entry characteristics \\
\hline 5. & Parental education level & CCSEQ & Entry characteristics \\
\hline 6. & Number of terms enrolled & College records & Goal commitment \\
\hline 7. & College GPA & College records & Goal commitment \\
\hline 8. & Number of credits this term & College records & Goal commitment \\
\hline 9. & $\begin{array}{l}\text { Number of work hours } \\
\text { per week }\end{array}$ & CCSEQ & Goal commitment \\
\hline
\end{tabular}


Table 2 (continued)

$\begin{array}{lll}\text { Variable } & \text { Source } \quad \text { Category }\end{array}$

10. Reason for attending college now

CCSEQ Goal commitment

11. Educational aspiration

CCSEQ

Goal commitment

12. Participation in campus activities

CCSEQ Integration

13. Contact with faculty outside of class

CCSEQ

Integration

14. Use of college support services

CCSEQ

Integration

15. Use of English language

CCSEQ

Integration

16. Perception of belonging

CCSEQ

Integration

17. Perception of validation

CCSEQ

Integration

\section{Data Analysis}

At the completion of the term, information was retrieved from the college records to discover the students who completed and the students who did not complete the term. Frequency distributions and descriptive statistics were compared between the two groups on the three groups of variables: background characteristics, goal commitment variables, and integration variables. To further identify the best differentiators of term completers and non-completers, data collected in Phase 1 were subjected to discriminant analysis to find an optimal set of variables that differentiated the two groups from each other (Tashakkori \& Teddlie, 1998). Discriminant analysis was also appropriate for this phase of the study because it provided an opportunity to examine which variables may be used to effectively predict group membership (Ary, Jacobs, \& Razavieh, 2002). 


\section{Phase 2}

Phase 2 was conducted to collect and analyze data from funnel-sequenced interviews which started with very broad questions and gradually limited the scope of the questions to a few focused issues. According to Tashakkori and Teddlie (1998), this type of interview is directly applicable to mixed method research. Interviews were conducted to discover additional data not revealed by the questionnaire but which may have influenced the student to withdraw or to persist. Funnel sequenced probes progressed from general to very specific as the interview progressed.

The four measures of trustworthiness in qualitative research introduced by Lincoln and Guba (1985) have evolved into internal validity, external validity, reliability, and objectivity. This study estimated internal validity, which assumes a causal relationship between dependent and independent variables, and external validity which infers that this causal relationship can be generalized to other similar persons and settings. Qualitative research uses a variety of viewpoints or lens to estimate credibility in a study, and this researcher has been especially aware of her presence and its implications for this study. It is inevitable that a researcher's presence has implications for how data is collected and more importantly, how data are interpreted. For example, this researcher was concerned that the students who were asked to participate in the study by completing the survey questionnaire and participating in interviews would agree to do so because of the position of the researcher. This type of influence, which Maxwell (1996) referred to as “reactivity,” could have been a disruptive element in this study. As a result additional care was taken to ensure that students understood that participation in the study was a voluntary activity, and that there was no consequence or compensation to not 
participating. This researcher concerns were alleviated once she experienced the evident comfort with which some students chose not to participate in the study. A total of 233 students were invited to participate in the study, and 208 students completed the survey questionnaire.

The validity of Phase 2 of this study depended on triangulation, member checking, and thick description. Triangulation collected and examined data from college records, questionnaires, and interviews to form themes in the study. The particular lens of the researcher determined whether the data was saturated to establish good themes or categories. Member checking involved the participants of the study in reviewing transcripts of the interviews to establish the accuracy of their account. According to Lincoln and Guba (1985), member checking is the most crucial technique for establishing credibility in a study. All the interviewees were invited to review the transcript of their interviews to verify the accuracy of the transcript. Three students who were interviewed looked at their transcript and verified that it was accurate; the remaining 9 students did not come to review their transcript. Finally, credibility in this phase of the study was supported and reinforced by thick description, providing detailed accounts of interview interactions and accounts, and giving a detailed interpretation of how people feel (Denzin, 1989).

The position of the researcher as the Associate Dean of the ESL/Reading/SLS Department proved to be inconsequential to the study as far as student participation was concerned. This was not the first time that a doctoral student-researcher had enlisted the participation of these ESL students. Many of them have completed several survey questionnaires or participated in focus groups for doctoral students' research studies. The 
questionnaires were distributed in classes with the help of instructors. In addition to formally securing the students' consent, the researcher explained that participation was voluntary, and there was no reward or consequence to participation. Consideration was given to the possibility that students would participate because of the position of the researcher; however, some students decided not to complete the survey and there was no attempt by the researcher to change that decision. Though some of the students who completed the questionnaire were aware of the researcher's position, none of the students who participated in interviews have ever met the researcher personally. Recognizing researcher reflexivity as an important validity procedure (Creswell \& Miller, 2000), this researcher considered her position as the department dean for ESL and the EAP Program to be a bias that shaped this inquiry. Without hesitation, she admits to a deep desire to have these ESL students experience success in their academic pursuit; to experience academic success, students need to persist, at least to the completion of their academic goal. Therefore, the discovery of additional variables that predicts persistence for ESL students is of special interest to this researcher.

\section{Participants}

Phase 2 participants were selected for interviews from the sample studied in Phase 1. Six students who withdrew in the course of the term and six students who completed the term were interviewed. This purposeful sample (Creswell \& Plano Clark, 2007) was appropriate at this stage of the study because the primary intent of Phase 2 was to collect additional data regarding those factors that influenced the decision of non completers to withdraw before the end of the term and of completers to persist. A total of 19 students withdrew during the term, but 13 of them withdrew before the Phase 1 survey was 
conducted, and therefore did not complete the questionnaire. The six students who withdrew after the survey was conducted were invited to participate in the interviews in Phase 2. In order to secure a matching number of interviews with completers, the invitation was extended to all the Phase 1 completers. The first male student who responded was accepted, and the first 5 female students who responded were accepted. This completer group matched the gender composition of the non completer group, and no attempt was made to match the two groups in other ways (i.e., age, country of birth, native language, or level). These 12 students were all enrolled in the following term.

\section{Variables and Measurement}

The data generated from Phase 1 was analyzed and an interview guide (see Appendix C) was developed from the analysis. Although the interview probes might ask for expansion of answers to Phase 1, every effort was made to allow the issues to develop in an emergent manner during the course of the session. In other words, the main goal of the interview was to discover additional personal, social, and institutional factors, through richer and fuller responses, that might have contributed to the students' withdrawal.

\section{Data Collection}

Interview sessions were digitally recorded with the permission of the interviewees, and archived according to Florida International University’s Regulations for Thesis and Dissertation Preparation. Before the interview started, the researcher introduced herself to each student in her role as a doctoral student researcher, and explained the research question and focus of the study. She invited each student to ask questions or share comments before the interview began. There were no questions or comments before the interview, but there were some questions and comments after the 
interview formally ended. These were summarized, collected and preserved as field notes and added to the body of data. Each interview lasted approximately one hour, and all the participants agreed to permit digital recording. Following each interview, the recorded dialogue was transcribed by the researcher and the transcript used for data analysis. Participants' confidentiality was maintained throughout the process as provided for by the informed consent policies and procedures at Florida International University and Broward College.

\section{Data Analysis}

The data collected during the interview phase (Phase 2) of the study was analyzed by using a constant comparative method defined by Glaser and Strauss (1967) as a process that combines inductive category coding with simultaneous comparison of all units of meaning obtained, for a process of continuous refinement. A coding grid was developed, using the 3 basic categories from the interview protocol: background, goal commitment, and integration. Initial analysis uncovered several themes that fit well within each of these categories, including pre college experiences, time management stress, and connecting with others on campus. The interview probes which followed up on initial questions funneled information from general to very specific. For example, all the interviewees said that there was a college employee who had been helpful to them during the term; but there was varying responses when asked to be specific about the help received from the college employee. Some responses were specific, i.e., "one of the lab helpers in the ESL lab, she really helped me a lot during that class, making me do more work about writing and grammar and punctuation and everything. She really helped out that semester." Other responses remained general despite the probe. For example, a 
student who was not comfortable asking questions of the instructor in the classroom or connecting to a classmate, had instead made a connection with an advisor, who she said had been helpful to her. In response to the probe of how the advisor had been helpful to her, she responded, "she’s kind of my friend now." It was to this person that she directed her questions about campus resources as well as about the content of the course. This self-assessed shy student identified music as her best medium of expression and invited the researcher to her next musical play performance on campus.

Themes in each category were coded in a different color, and a second reading of the transcripts merged, solidified or omitted themes. Some themes emerged in the same way in every interview, that is, “...because there is no time;” while other messages did not fit into any category and was therefore omitted from the analysis. For example, the male non completing student expressed some expectation that the interview would possibly result in a reconsideration of his withdrawal from the course.

The researcher did not want to end the coding process with only a list of themes, and so reexamined the themes in search of a developing conceptual schema. What emerged naturally from the interview data, and also responded to the research question, is that both groups of students shared common characteristics and concerns. The difference was that completing students were able to identify some of the things that helped them to complete the term; whereas non completing students could report on some of the things they failed to do that caused them to not complete the term. This approach to coding and analyzing the interview data facilitated the discovery of additional factors that influenced in-term withdrawal for non completers, and revealed other factors that indirectly influenced completers 'decisions to persist. 


\section{Summary}

This chapter presented the selection and analysis of data used to find possible answers to what predicts ESL students’ persistence to term completion at a community college.

A parallel mixed-method research design was used to analyze data collected from students and from preexisting college records in Phase 1 and Phase 2 of the study. The participants in the study were ESL students enrolled in EAP courses on Broward College’s Central Campus. Data were collected in Phase 1 from a combination of college records and survey items and through simple discriminant analysis, established the best possible weighted predictor variables from among entry characteristics, goal commitment and integration variables. In Phase 2, semi-structured interviews were conducted with a purposive sample of students included in Phase 1 who withdrew and who completed the term. This parallel mixed method research design was appropriate to this study for a fuller discovery of the variables considered in this study. Semi-structured interviews yielded data that shed new light, raised awareness and understanding, and uncovered new variables that impact language minority students’ in-term persistence. 


\section{Chapter IV}

\section{Results}

The purpose of this study was to identify those factors that predict in-term persistence of community college English-as-a-Second-Language students. The previous chapter outlined the research design, including research setting, population and sample data, and data collection instruments and procedures. This chapter presents a report of background and entry characteristics, goal commitment data and integration data from the participants; the analysis procedures and the results from Phase 1 and Phase 2 as related to the purpose of the study are also presented in this chapter.

\section{Phase 1}

The participants for this study were drawn from students enrolled in levels two through six of a community college English for Academic Purpose (EAP) program. Students from 11 classes ( $n=233$ ) were invited to participate in Phase 1 of the study, and a total of 208 students completed the Community College English-as-a-Second-Language Student Questionnaire (CCESQ). All participating students’ responses were recorded on an Excel spreadsheet and later downloaded in SPSS version 17. Of the 26 items on the CCESQ, 9 items requested information on background and entry characteristics. Background information included gender, age, marital status, and racial/ethnic identification; and entry characteristics items included country of birth, native language, pre U.S. years of English study, and parental education. Following is the data collected in Phase 1 from participants' responses on background and entry characteristics. 


\section{Background and Entry Characteristics}

The entry characteristics of the participants include age, gender, racial/ethnic identification, pre U.S. years of English study, and parental education. Marital status information collected as part of the background data was not included in this report on entry characteristics since this item is subject to change either after a student enters college or in the course of a term. College placement data were also excluded since the status of placement in ESL courses is the same for all the students in this study.

The majority of the sample was comprised women over the age of 30 . The statistical data showed that the mean age of participants in the study was 32.5years and $67.3 \%$ were female. Students of Hispanic background accounted for $66 \%$ of the study participants. These students came from Spanish language speaking countries in the Caribbean, Central America and South America. The next largest group (15\%) selfidentified as being Black non Hispanic, and was comprised of students who came from the Caribbean, Africa and the United States. Participants reported 37 different countries of birth, with the largest single percentage (28.3\%) reporting Colombia as their country of birth. Among the participants, eight students reported the United States as their country of birth, and 23 students reported that they completed high school in the United States. Participants also reported 24 different native languages, and those students born in the United States, identified the native language of the country where they completed high school as their native language. There were no students in the study who reported English as their native language.

Study participants also reported on their years of English study before coming to the United States. Though 25\% of respondents reported no English study prior to coming 
to the United States, 45\% of respondents reported having 2 or more years of English study prior to coming to the United States.

The diversity of pre-college English experience is one of the distinctions of community college ESL students that might impact the student's decision to withdraw or to persist. This variable is not even consistent for students within the same native language subset. For example, the student from Nicaragua, whose native language is Spanish, may have studied English for 8 years in elementary and high school, whereas the student from Peru, whose native language is also Spanish, may have had no English study prior to coming to the United States. Similarly, though Urdu is the primary language of the student from Pakistan, English was considered his or her second language throughout elementary and high school. In contrast, a student from Moldova who studied only in Moldavian throughout elementary and high school experience is receiving his or her first English lesson in college in the United States. Frequency distribution for entry characteristics are reported in Table 3.

Table 3

Frequency Distributions for Entry Characteristics

\begin{tabular}{|c|c|c|}
\hline Personal Data & Frequency & Percent \\
\hline \multicolumn{3}{|l|}{ Age } \\
\hline$<20$ years & 17 & 8.2 \\
\hline $20-29$ years & 95 & 45.9 \\
\hline $30-39$ years & 39 & 18.9 \\
\hline
\end{tabular}


Table 3 (continued)

\begin{tabular}{|c|c|c|}
\hline Personal Data & Frequency & Percent \\
\hline \multicolumn{3}{|l|}{$\overline{\text { Age }}$} \\
\hline $40-49$ years & 37 & 17.9 \\
\hline >50 years & 15 & 7.2 \\
\hline Total & 203 & 98.1 \\
\hline No response & 4 & 1.9 \\
\hline Total & 208 & 100.0 \\
\hline \multicolumn{3}{|l|}{ Gender } \\
\hline Male & 67 & 32.4 \\
\hline Female & 140 & 67.6 \\
\hline Total & 208 & 100.0 \\
\hline \multicolumn{3}{|l|}{ Racial/ethnic identification } \\
\hline Asian/Pacific Islander & 12 & 5.8 \\
\hline Black non Hispanic & 31 & 15.0 \\
\hline Hispanic/Latino & 137 & 66.1 \\
\hline White non Hispanic & 22 & 10.6 \\
\hline \multicolumn{3}{|l|}{ American Indian or } \\
\hline Alaska Native & 0 & \\
\hline Other & 5 & 1.9 \\
\hline Total & 208 & 99.5 \\
\hline \multicolumn{3}{|l|}{ High School Experience } \\
\hline \multicolumn{3}{|l|}{ Completed high school } \\
\hline in country of birth & 176 & 85.0 \\
\hline \multicolumn{3}{|l|}{ Completed high school } \\
\hline in the U.S. & 22 & 10.6 \\
\hline
\end{tabular}


Table 3 (continued)

Personal Data

Frequency

Percent

Completed high school

in a country other

than country of birth

or the U.S.

9

4.4

Total

208

100.0

In addition to age, gender, and high school experience, study participants were asked to indicate years of parental schooling. Otero, Rivas \& Rivera (2007) identify parental education as one of the characteristics that exerts influence on students' decision to persist or withdraw. The data gathered from the survey show that $12.5 \%$ of participants did not respond to the item of maternal years of schooling and $13.9 \%$ did not respond to the item of paternal years of schooling. The data collected on parental education is provided in Table 4.

Table 4

Parental Education

\begin{tabular}{lll} 
Parent & Number & Percent \\
\hline Mother's education & & \\
$\quad$ high school & 75 & 36.05 \\
Completed high school & 39 & 18.75 \\
\hline & & (table continues)
\end{tabular}


Table 4 (continued)

\begin{tabular}{lrr}
\hline Parent & Number & Percent \\
\hline 1-3 years of college & 22 & 10.57 \\
Completed college + & 44 & 21.15 \\
Total & 180 & 86.53 \\
No response & 28 & 13.47 \\
Total & 208 & 100.00 \\
Father’s education & 75 & 36.05 \\
$<$ high school & 26 & 12.50 \\
Completed high school & 20 & 9.62 \\
1-3 years of college & 57 & 27.40 \\
Completed college + & 178 & 85.58 \\
Total & 30 & 14.42 \\
No response & 208 & 100.00 \\
Total & &
\end{tabular}

The discriminant analysis that was run on the data to test for persistence between completers and non completers, found no significant predictors among entry characteristic variables. The results of the test of equality for pre entry characteristics are reported in Table 5. 
Table 5

Tests of Equality of Group Means for Pre Entry Characteristics

\begin{tabular}{lccccc}
\hline Characteristic & Wilks' Lambda & F & df1 & df2 & Sig. \\
\hline $\begin{array}{l}\text { Age } \\
\text { Racial/ethnic }\end{array}$ & .999 & .233 & 1 & 190 & .630 \\
$\begin{array}{l}\text { identification } \\
\begin{array}{l}\text { Pre U.S. years of } \\
\text { English study }\end{array}\end{array}$ & 1.000 & .073 & 1 & 190 & .787 \\
$\begin{array}{l}\text { Mother's years of } \\
\text { schooling }\end{array}$ & .998 & .389 & 1 & 190 & .533 \\
$\begin{array}{l}\text { Father's years of } \\
\text { schooling }\end{array}$ & .997 & .640 & 1 & 190 & .425 \\
\hline
\end{tabular}

\section{Goal Commitment}

Tinto’s (1987) original model of student departure held that students enter college with certain commitments both to finishing college and to staying at their college. This variable was assessed on the CCSEQ by asking participants to respond to items on number of credits enrolled this term, number of hours of study each week, number of hours of work each week, and their reason for attending college at this time. Data on the number of terms enrolled and GPA were collected from college records.

The largest single percentage (35.6\%) of participants were registered for 6 credits, with the next largest percentage (17.4\%) registered for 12 credits. Respondents spent a wide range of hours (1-40) studying for classes each week, with almost half (47.6\%) of the sample population spending less than 6 hours each week preparing for classes. 
Respondents also reported the number of hours worked per week, and if they worked, how their jobs affected their college work. Over $40 \%$ of the respondents reported that they work more than 35 hours per week, and as many as 30\% of those who work reported that they worked for 40 hours each week. Only $17.7 \%$ of respondents did not work, and a majority of working respondents (65.5\%) reported that their job took time from their schoolwork.

Community college students have very diverse reasons for attending college (Bean, 1990; Otero et al., 2007; NCES, 2008), but a considerable percentage (41.8\%) of this study participants indicated that their reason for being in college now was either to obtain an Associate Degree or to prepare to transfer to a 4-year college or university. Almost half of the respondents (43.3\%) ranked "to improve my English language skills" as their primary reason for attending college. Though $4.8 \%$ of respondents indicated that they sought skills necessary to get a job as their primary reason, less than $3 \%$ were in college primarily to obtain skills necessary to retrain or advance in a current job. When asked "what is the highest educational level you plan to complete," participants' responses item indicate a majority (68.7\%) who intend to pursue a bachelor's degree or higher, and $20.8 \%$ whose ultimate educational goal is the completion of an associate degree. Frequency distributions for the goal commitment variables are presented in Table 6. 
Table 6

Frequency Distributions for Goal Commitment Variables

\begin{tabular}{|c|c|c|}
\hline Variable & Distribution & Percent \\
\hline \multicolumn{3}{|c|}{ Number of credits enrolled this term } \\
\hline$<6$ credits & 54 & 26.0 \\
\hline 6 credits & 74 & 35.6 \\
\hline $7-9$ credits & 34 & 16.3 \\
\hline$>9$ credits & 46 & 22.1 \\
\hline Total & 208 & 100.0 \\
\hline \multicolumn{3}{|c|}{ Number of hours of study each week } \\
\hline$>6$ hours & 99 & 47.6 \\
\hline $7-15$ hours & 80 & 38.5 \\
\hline$<16$ hours & 27 & 13.0 \\
\hline No response & 2 & 0.9 \\
\hline Total & 208 & 100.0 \\
\hline \multicolumn{3}{|c|}{ Number of hours of work each week } \\
\hline Do not work & 37 & 17.8 \\
\hline$>8$ hours & 4 & 1.9 \\
\hline $8-15$ hours & 8 & 3.8 \\
\hline $16-20$ hours & 10 & 4.8 \\
\hline $21-35$ hours & 36 & 17.3 \\
\hline$<35$ hours & 88 & 42.3 \\
\hline No response & 25 & 12.0 \\
\hline Total & 208 & 100.0 \\
\hline \multicolumn{3}{|c|}{ Reason for attending college at this time } \\
\hline \multicolumn{3}{|c|}{ To improve English } \\
\hline language skills & 90 & 43.2 \\
\hline
\end{tabular}


Table 6 (continued)

\begin{tabular}{lrr}
\hline \multicolumn{1}{l}{ Variable } & Distribution & Percent \\
\hline $\begin{array}{l}\text { To satisfy a personal interest } \\
\text { To obtain skills necessary }\end{array}$ & 11 & 5.3 \\
to get a job & 10 & 4.8 \\
To obtain skills necessary to & & \\
retrain, remain current or & & \\
advance in a current job & 6 & 2.9 \\
To obtain an & & \\
Associate Degree & 29 & 14.0 \\
To prepare to transfer to a & & \\
4-year college or university & 57 & 27.4 \\
No response & 5 & 2.4 \\
& 208 & 100.0 \\
Total & \\
Highest Educational Level Student Plan to Complete & 1.4 \\
This course only & 3 & 7.2 \\
All the ESL courses & 15 & 20.8 \\
Associate Degree & 43 & 68.7 \\
Bachelor's Degree or higher & 143 & 1.9 \\
No response & 4 & \\
Total & 208 & \\
\hline
\end{tabular}

The results of the test of equality of means for the commitment variables are presented in Table 7. 
Table 7

Test of Equality of Group Means for Commitment Variables

\begin{tabular}{lccccc}
\hline & Wilks’ Lambda & F & df1 & df2 & Sig. \\
Variable & & & & & \\
\hline Work hours per week & 1.000 & .004 & 1 & 190 & .947 \\
$\begin{array}{l}\text { Does college affect } \\
\text { your work }\end{array}$ & .999 & .170 & 1 & 190 & .681 \\
Term credit load & .997 & .495 & 1 & 190 & .483 \\
$\begin{array}{l}\text { Day or evening classes } \\
\text { Study hours per week }\end{array}$ & .990 & 1.936 & 1 & 190 & .166 \\
Educational goal level & 1.000 & .084 & 1 & 190 & .772 \\
Reason for attending & & & & 1 & \\
college at this time & 1.000 & .004 & 1 & 190 & .951 \\
\hline
\end{tabular}

\section{Integration Variables}

Academic and social integration are commonly used to examine persistence in college based on Tinto’s (1996) persistence model. Concerning integration, Tinto proposes that students are more likely to persist if they become connected to the academic and social life of the campus. Connecting to instructors and other individuals on campus, participating in clubs and other organizations, and spending unscheduled time on campus would signal such a connection. Participants in the study were asked to respond to a variety of items to address integration variables, such as their interactions with instructors, participation in class discussions, participation in clubs or student organizations, use of college facilities, and their feeling about being a member of the campus community. They were also asked about time spent on campus that was not required to attend classes or complete lab hours. Almost 30\% of respondents reported 
spending no time on campus that was not required to attend classes or labs, while others reported spending a broad range of hours each week of non-required time on campus. One student reported spending 28 hours of non-required time on campus.

When asked about the number of visits to an advisor or success specialist this term, $34.6 \%$ of participants indicated that they had made one visit only, while $24 \%$ of respondents reported no visits to an advisor or success specialist for the term. Fifty-nine percent of respondents never met with an instructor in his or her office, 31\% reported never emailing their instructor; but over $47 \%$ of respondents agree that instructors generally remember their names, and $42.5 \%$ of respondents agreed with having at least one instructor at the college whom they thought of as a mentor. Fifty-two percent of respondents reported frequent use of the library and $42.5 \%$ reported frequent use of the cafeteria. More than $82 \%$ of respondents have never attended a meeting of a student club or organization, yet a majority (58.2\%) indicated that they felt like a member of the campus community.

Frequency distributions for integration variables are summarized in Tables 8 and 9. Table 8 Frequency Distribution for Integration Variables

\begin{tabular}{lccccc}
\hline \multicolumn{1}{c}{ Variable } & Often & Occasionally & Never & $\begin{array}{c}\text { No } \\
\text { Response }\end{array}$ & Total \\
\hline $\begin{array}{l}\text { Participated in class } \\
\text { discussions }\end{array}$ & 110 & 82 & 7 & 9 & 208 \\
$\begin{array}{l}\text { Studied course material with } \\
\text { other students }\end{array}$ & 52 & 104 & 43 & 9 & 208 \\
\hline & & & & (table continues)
\end{tabular}


Table 8 (continued)

\begin{tabular}{|c|c|c|c|c|c|}
\hline Variable & Often & Occasionally & Never & $\begin{array}{c}\text { No } \\
\text { Response }\end{array}$ & Total \\
\hline $\begin{array}{l}\text { Asked an instructor about } \\
\text { course content or grade }\end{array}$ & 69 & 106 & 23 & 10 & 208 \\
\hline $\begin{array}{l}\text { Met with an instructor in } \\
\text { his/her office }\end{array}$ & 15 & 57 & 124 & 12 & 208 \\
\hline $\begin{array}{l}\text { Discussed educational or } \\
\text { career plans with an instructor }\end{array}$ & 20 & 70 & 109 & 9 & 208 \\
\hline $\begin{array}{l}\text { Talked informally with an } \\
\text { instructor about common } \\
\text { interests or current events }\end{array}$ & 17 & 69 & 111 & 11 & 208 \\
\hline $\begin{array}{l}\text { Discussed academic } \\
\text { performance, academic } \\
\text { difficulties, or personal } \\
\text { problems with an instructor }\end{array}$ & 24 & 63 & 112 & 9 & 208 \\
\hline $\begin{array}{l}\text { Used email to communicate } \\
\text { with instructor }\end{array}$ & 28 & 100 & 64 & 16 & 208 \\
\hline Used the library & 109 & 78 & 14 & 7 & 208 \\
\hline Used the cafeteria & 32 & 75 & 91 & 10 & 208 \\
\hline $\begin{array}{l}\text { Attended Student Organization } \\
\text { or Club Meeting }\end{array}$ & 4 & 18 & 174 & 12 & 208 \\
\hline $\begin{array}{l}\text { Participated in events } \\
\text { sponsored by a student } \\
\text { organization or club }\end{array}$ & 1 & 13 & 184 & 10 & 208 \\
\hline
\end{tabular}


Table 9

Frequency Distribution for Integration Variables

\begin{tabular}{lcccccc}
\hline \multicolumn{1}{c}{ Variable } & $\begin{array}{c}\text { Strongly } \\
\text { agree }\end{array}$ & Agree & Disagree & $\begin{array}{c}\text { Strongly } \\
\text { Disagree }\end{array}$ & $\begin{array}{c}\text { No } \\
\text { response }\end{array}$ & Total \\
\hline $\begin{array}{l}\text { My instructors generally } \\
\text { remember my name }\end{array}$ & 100 & 86 & 10 & 2 & 10 & 208 \\
$\begin{array}{l}\text { I receive prompt feedback } \\
\text { from instructors on my } \\
\text { performance }\end{array}$ & 71 & 102 & 16 & 2 & 13 & 208 \\
$\begin{array}{l}\text { My instructors understand } \\
\text { that students come from } \\
\text { different backgrounds }\end{array}$ & 107 & 78 & 7 & 4 & 12 & 208 \\
$\begin{array}{l}\text { I am encouraged by my } \\
\text { instructors to openly share } \\
\text { my views in class }\end{array}$ & 79 & 92 & 20 & 4 & 12 & 208 \\
$\begin{array}{l}\text { I feel like my personal and } \\
\text { family history is valued in } \\
\text { class }\end{array}$ & 38 & 84 & 58 & 9 & & \\
\end{tabular}

10.

Results of the test of equality for the integration variables are presented in Table

Table 10

Test of Equality of Group Means for Integration Variables

\begin{tabular}{lccccc}
\hline Variables & Wilks’ Lambda & F & df1 & df2 & Sig. \\
\hline Work hours per week & 1.000 & .004 & 1 & 190 & .947 \\
Non class/lab hours on campus & .994 & 1.171 & 1 & 190 & .281 \\
Visits to advisor/success specialist & .994 & 1.134 & 1 & 190 & .288 \\
Participate in class discussion & .999 & .187 & 1 & 190 & .666 \\
Studied with other students & .999 & .189 & 1 & 190 & .665 \\
Asked instructor about & & & & & \\
\multicolumn{1}{c}{ course content } & .999 & .217 & 1 & 190 & .642 \\
\hline
\end{tabular}


Table 10 (continued)

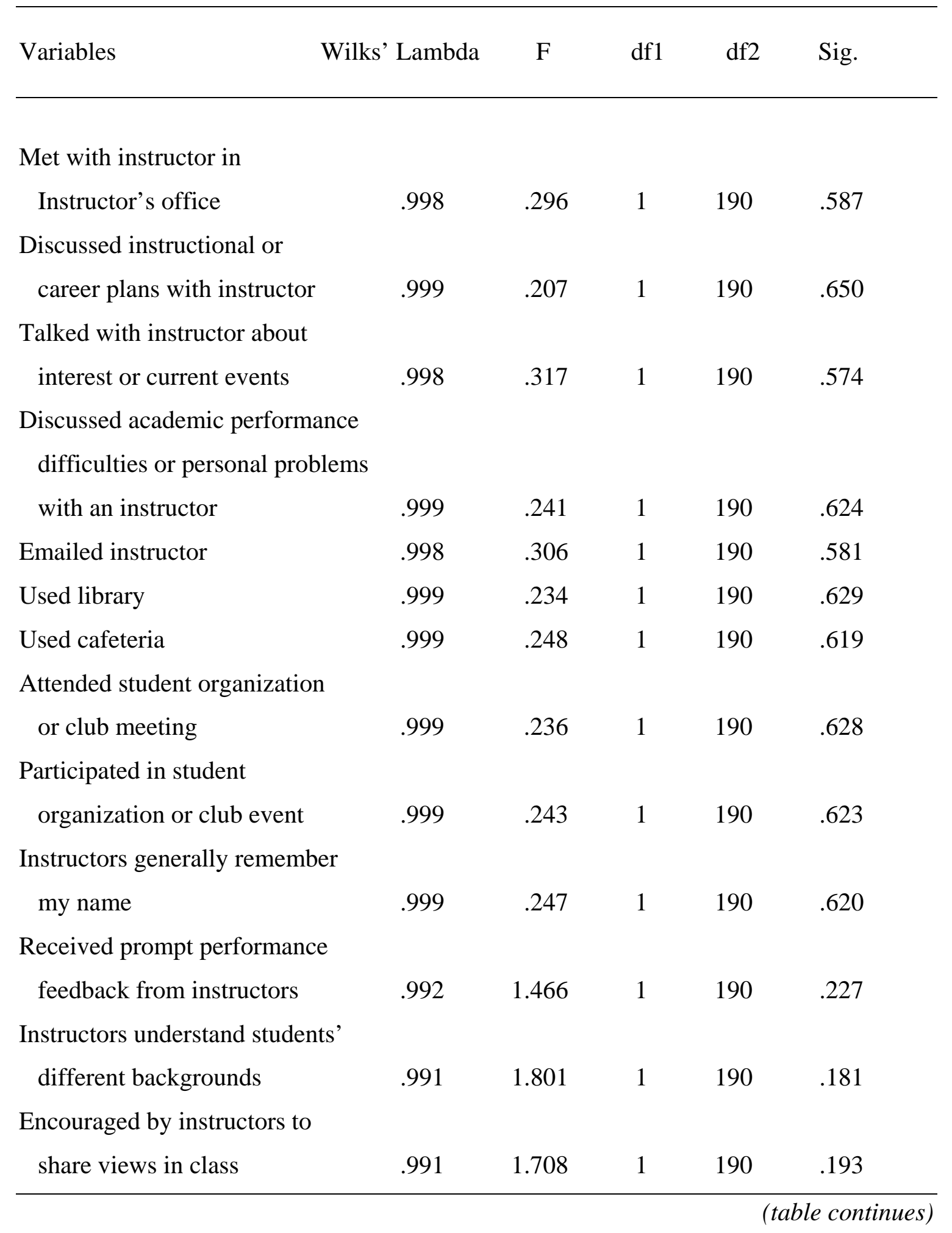


Table 10 (continued)

\begin{tabular}{lccccc}
\hline & Wilks’ Lambda & F & df1 & df2 & Sig. \\
$\begin{array}{lllll}\text { Variables } & & & & \\
\text { Personal family history is } \\
\quad \text { valued in class }\end{array}$ & .998 & .468 & 1 & 190 & .495 \\
$\begin{array}{l}\text { Feel like a member of the } \\
\text { campus community }\end{array}$ & .998 & .297 & 1 & 190 & .587 \\
$\begin{array}{l}\text { Thought of at least one } \\
\text { instructor as a mentor }\end{array}$ & .997 & .490 & 1 & 190 & .485 \\
$\begin{array}{l}\text { Time in the US } \\
\text { Immigration/residency status }\end{array}$ & .999 & .159 & 1 & 190 & .691 \\
\hline
\end{tabular}

The use of English language is a measure of integration for ESL students, and this variable was addressed in the survey by the inclusion of two items. First, students were asked to indicate what language they usually use in the daily activities of interactions with family, with friends, at work, when watching TV, watching cable TV, listening to radio/music, and using the Internet. When responding to use of English language in daily interactions, participants reported use of their native language with family (71\%), with friends (34\%), at work (7\%), to watch TV (10.2\%), to watch cable TV (6.3\%), to listen to the radio (10.2\%), and to use the Internet (5.3\%).

Participants were also asked to report on the best fit to "most of my friends are:” (a) people who speak your native language and share your native culture; (b) people who speak a different language from a different culture, not American; (c) Americans who speak the same language as you; and (d) Americans who speak English. Responses to this item indicate that most participants (65.7\%) are people who speak their native language 
and share their native culture. Participants' reported use of English is summarized in

Table 11.

Table 11

English Language Use

\begin{tabular}{|c|c|c|c|c|}
\hline $\begin{array}{c}\text { Daily } \\
\text { Activity }\end{array}$ & $\begin{array}{c}\text { More Native } \\
\text { Language } \\
\%\end{array}$ & $\begin{array}{c}\text { More English } \\
\text { Language } \\
\%\end{array}$ & $\begin{array}{l}\text { Both Native } \\
\text { and English } \\
\text { Language \% }\end{array}$ & $\begin{array}{c}\text { No } \\
\text { Response \% }\end{array}$ \\
\hline \multicolumn{5}{|l|}{ Language used } \\
\hline with family & 71.0 & 7.2 & 17.8 & 4.0 \\
\hline \multicolumn{5}{|l|}{ Language used } \\
\hline with friends & 33.3 & 22.2 & 41.5 & 3.0 \\
\hline Language used at work & 6.8 & 42.5 & 24.6 & 26.1 \\
\hline \multicolumn{5}{|l|}{ Language used to } \\
\hline watch TV & 10.0 & 58.5 & 28.0 & 3.5 \\
\hline \multicolumn{5}{|l|}{ Language used to } \\
\hline watch cable & 6.3 & 59.9 & 25.6 & 8.2 \\
\hline \multicolumn{5}{|l|}{ Language used to } \\
\hline listen to radio & 10.0 & 51.7 & 33.8 & 3.5 \\
\hline \multicolumn{5}{|l|}{ Language used } \\
\hline on Internet & 5.3 & 56.5 & 34.3 & 3.9 \\
\hline
\end{tabular}

The frequency distributions for the use of the English language reflected language used to watch TV as significant at .024 and language use on the Internet as significant at .028. The summary of the test of equality of means for language usage is presented in Table 12. 
Table 12

Test of Equality of Group Means for English Language Use

\begin{tabular}{|c|c|c|c|c|c|}
\hline English Language Use & Jilks’ Lambda & $\mathrm{F}$ & df1 & df2 & Sig. \\
\hline Language used with family & .999 & .197 & 1 & 190 & .658 \\
\hline Language used with friends & .999 & .221 & 1 & 190 & .639 \\
\hline Language used at work & .999 & .095 & 1 & 190 & .758 \\
\hline Language used to watch TV & .973 & 5.182 & 1 & 190 & $.024^{*}$ \\
\hline Language used to watch cable & .994 & 1.133 & 1 & 190 & .288 \\
\hline Language used to listen to radio & .999 & .184 & 1 & 190 & .669 \\
\hline Language used on Internet & .975 & 4.877 & 1 & 190 & $.028^{*}$ \\
\hline
\end{tabular}

\section{Summary of Phase 1 Results}

The study proposed a comparison of frequency distributions and descriptive statistics for term completers and non completers on the three groups of variables: background characteristics, goal commitment variables, and integration variables. Additionally, the data collected in Phase 1 were subjected to discriminant analysis and did not find an optimal set of variables that differentiated the two groups from each other at a high level of reliability. Descriptive statistics from SPSS were used to report the resulting data for Phase 1.

On most of the variables, the results are not significantly different for completing and non completing students. However, the following distinctions identified as predictors of persistence in current research (Barbatis, 2010; Fike, 2008; Roberts \& Styron, 2010) were found to exist between the two groups of students. Non completing students worked 
an average of 10 hours more per week than completing students. Half of the non completing students reported using their native language exclusively at work, while less than $25 \%$ of completers reported using their native language at exclusively work. Non completing students never participated in any organizations on campus, and half of them did not visit an advisor this term, while $6.5 \%$ of completers occasionally participated in a an organization on campus and 34.5\% visited an advisor at least once in the term. Non completing students spent an average of 5 hours each week on campus that was not required for class or labs, and completing students spent an average of 3 hours; non completers never attended a meeting of an organization or club on campus, but only $15 \%$ of completers reported attending a club or student organization activity on campus.

\section{Phase 2}

Participants in Phase 2 were selected from the sample studied in Phase 1. Six students who withdrew in the course of the term and six students who completed the term were invited to participate in interviews. Interviews were conducted in Phase 2 to discover additional personal, social, and institutional factors that might have contributed to students’ withdrawal and that may not have been discovered from the data collected in Phase 1. Interview probes were designed to expand on answers given in Phase 1, but every effort was made to allow these issues to develop in an emergent manner in the course of the session. Interviews lasted between 45 minutes and one hour and 15 minutes, and were digitally recorded with the permission of the participants. The interviews were subsequently transcribed, coded and analyzed using the constant comparative method as described by Glaser and Strauss (1967). The data were initially coded into as many categories as possible and then refined to focus on details of predominant categories. 
Explicit themes were identified and all the emergent topics were noted. Focus was then given to those topics that emerged in the interviews. For example, both completers and non completers were equally preoccupied with time, work, and connections. There were repeated messages of challenges with time for labs, time for family, and time for work; all of these messages were communicated in relationship to time to do homework. Subsequent readings of the interview transcripts coded "time" messages into 3 categories: time for school, time for work, and time for family. Likewise, "work” messages were coded into 3 categories: part time work, full time work, and how work helped or hindered the preparation for classes. Another category that surfaced was the connections that students made to others on campus. These messages were coded into the following categories: connections to classmates/other students, connections to any college employee, connections to advisors/student success specialist, or connections to instructors. Though the researcher kept a tally sheet of the frequencies of these categories, focus was given to the qualitative rather than the quantitative aspect of the communication messages. Therefore some irrelevant or less relevant categories were removed, and the remaining interrelated categories—characteristics, concerns, and recommendations_-formed the basis for comparison. Consistent with Janesick (1994), the interviewer used constant comparative analysis to look for information, decisions, and actions that occurred in the term and were related in the interview that could have predicted persistence.

All interviewees were identified by gender and level, and were asked to indicate whether they registered early, late or on time for the term of study. Early registration was indicated when the student registered as soon as the term schedule was available, and late 
registration was indicated when the student registered during the first week of the term. Otherwise, the student's registration was recorded as on time. Only one student among the completers registered late, and all of the non completers registered either early or on time. Five of the six interviewees in both categories were Hispanic, and the completers had an overall higher GPA than the non completers. Information on GPA was retrieved from college records, and basic demographic information and time of registration for Phase 2 participants are summarized in Table 13.

Table 13

Demographic Information, ESL Level, Registration Time, and GPA of Interviewees

\begin{tabular}{|c|c|c|c|c|c|c|}
\hline Student & GPA & Gender & $\begin{array}{c}\text { Native } \\
\text { Language }\end{array}$ & $\begin{array}{l}\text { Country } \\
\text { of Birth }\end{array}$ & Level & $\begin{array}{c}\text { Time of } \\
\text { Registration }\end{array}$ \\
\hline \multicolumn{7}{|c|}{ Completers } \\
\hline$\# 1$ & 4.0 & Male & Spanish & Venezuela & 4 & late \\
\hline \#2 & 3.0 & Female & Spanish & USA & 4 & on time \\
\hline \#3 & 4.0 & Female & Bengali & Bangladesh & 3 & on time \\
\hline$\# 4$ & 3.2 & Female & Spanish & El Salvador & 4 & early \\
\hline \#5 & 4.0 & Female & Spanish & Colombia & 4 & early \\
\hline \#6 & 3.1 & Female & Spanish & Colombia & 4 & early \\
\hline \multicolumn{7}{|c|}{ Non completers } \\
\hline$\# 1$ & 1.5 & Female & Spanish & Nicaragua & 3 & on time \\
\hline \#2 & 3.5 & Female & Spanish & Venezuela & 4 & early \\
\hline \#3 & 2.3 & Male & Spanish & Colombia & 3 & on time \\
\hline
\end{tabular}


Table 13 (continued)

\begin{tabular}{ccccccc}
\hline Student & GPA & Gender & $\begin{array}{c}\text { Native } \\
\text { Language }\end{array}$ & $\begin{array}{c}\text { Country } \\
\text { of Birth }\end{array}$ & Level & $\begin{array}{c}\text { Time of } \\
\text { Registration }\end{array}$ \\
\hline$\# 4$ & new & Female & Spanish & Peru & 2 & early \\
$\# 5$ & 2.8 & Female & Urdu & Pakistan & 5 & early \\
$\# 6$ & 2.6 & Female & Spanish & Ecuador & 4 & early \\
\hline
\end{tabular}

\section{Completer Characteristics}

The students who participated in interviews and who completed the courses for which they were registered in the term of study, shared only two common characteristics. Five of the six students who completed their term had previous college or English study experience, and four of the six students experienced no break in post-secondary study. Four of the six completers expressed areas of concern that affected their study, and the common concern in all four cases was not having enough time for lab and homework. Two of the six completers did not work, and of the four working completers, only one worked more than 15 hours each week. There were two characteristics shared by all six students who completed their courses in the term of study. First, completing students expressed commitment to a goal, and second, completing students connected to either an advisor or an instructor with whom they interacted on a regular basis. When one completing student expressed his goal to complete his degree, he was asked how he would achieve that goal. His response clearly indicated an early decision to persist and complete each step that eventually led to the completion of the term. 
First, I will plan out the term, how I think they're going to take it, then go to a counselor so that they can tell you if the way you did is right is wrong, then after you get the approval of the counselor for the next classes you're going to take and register early as possible so you're sure to get them, and after you're in the class, try to not to procrastinate to last minutes, and try to do everything on time.

One interview question asked students about a college employee who was helpful to them in the term of study. The interviewer explained that "college employee" included everyone who worked for the college, not just the classroom instructor. All of the six completers readily identified at least one college employee, and five of the six responders identified more than one college employee who was helpful to them in the term of study. College employees included instructors, academic advisors, financial aid advisors, lab assistants, and the department assistant. Instructors were identified by all completers as a college employee who was helpful to them, and many of the instructors were identified by name. With little encouragement, students talked about the specific occasion and the nature of the help they received, and one financial aid counselor was mentioned by name by 3 of the interviewees. When these 3 students were probed on their response, they reported that this counselor was "nice” and explained in "my language." Students also mentioned specific instructors who were helpful and what was the help that they received. Students were positively impressed that instructors offered and gave time to individually explain and tutor students in their offices.

Students were also asked about another student who was helpful to them in the term of the study. Every completing interviewee was able to identify another student or students from whom they received various kinds of help. One student told about the guy sitting next to him, and how "we usually did the homework and the papers that we had to do and the exercise in class, we did them together, and we helped each other during class 
and outside of class." Another student reported that classmates "gave me the push to get through the term and finish fast, and then you don't wait.” Despite one student's concern that she was the only non-Spanish-speaking student in the class, she still connected with a group of classmates with whom she always sat in class, and who were helpful to her "like if I missed something or if I asked something they know, they glad to help me.” Another student identified her "best friend ... I mean we start together with this and actually I met him here and we became a good friend, so every time that we had a work we get together and do it. Two persons think better than one, so if I have a mistake, he was helpful. It's still helpful.” One of the ways in which classmates were helpful to students specifically related to their struggle to speak English outside of class. One completing student who acknowledged that "the most important is the practice," remembered "some classmate they always push me to say in English,” even though that classmate also speaks Spanish. In addition to studying with a helpful student out of class and sharing with each other what one knew that the other needed to know, one completing student was brought to the college by the student who continued to be helpful to her. Completing students all expressed real connections to other students in their class.

The six completing students were asked to "describe some things you would recommend to another student to help him/her stay in school until the end of the term.” This probe frequently elicited an expression of the student's own commitment to the goal of staying in school, which was the second characteristic that all six completing students had in common. Though this expressed commitment to a goal took different forms among the six completers, they each identified a goal to which they were working. Registering for the class and completing the term was an integral part of that goal. One student's 
approach was strictly operational, "to plan out the term ... register as early as possible ... try not to procrastinate ... and try to do everything on time.” Another student discussed her own efforts to protect her GPA by withdrawing from a class in a previous term, but then concluded, “but I don’t like that, I like to finish what I start.” Another completer explicitly identified her goal by expressing, "We are here for learning. So before think like that, we have to keep in our mind and know the purpose to come over here. The reason they come over here is because of learning ... this is what I mean about the commitment ... I have to tell myself I just cannot withdraw myself, because nobody is going to force me here. If I want to learn, if I'm to go forward for a better education and a better life, I just cannot say things like that ...” When asked her thoughts on the difference between herself and a student who did not complete the term, one completer responded, "well me, I want to excel in my work, I want to have my profession, I want to succeed in life.”

\section{Completer Concerns}

Though two of the six completing students had no concerns for themselves, both of them expressed concerns for other students in the class. The other four students had concerns of their own that included financing their education, transportation to school, inadequate computer skills, and the pace of the work. One 47-year-old Asian student's concern came from her assessment that she is not from this generation, neither is she culturally familiar as are all the other students in her class. So "sometimes I feel left alone because I just cannot keep up.” The one common concern expressed by everyone, for themselves and for their classmates, was the concern for enough time. Because all of the EAP courses require lab time in addition to class time, all the students had concerns about 
having enough time for class, lab, homework, and "life.” One of the students who had no concerns for himself, was concerned for other "students who dropped out 'cause they were working and they didn't really have time to take that, it was a 6-credit course ... maybe that's the reasons that they dropped out ‘cause they didn't have time.” One completing student acknowledged that "when we come to the school, and I know we have a lot of stuff going on beside our stuff, and we get into the class, and you know, we have the tendency to run as soon as the class is over and as soon as we go home and easier could be done the homework and everything, this is not the real thing." One completer thought she had worked everything out to deal with work and class, "because it's no time, you know. I work.” In the words of this student,

At the beginning I was going to take 4 classes because it was good because it was Monday and Wednesday I had one class and Tuesday and Thursday I had the other one. But because the lab I couldn't take, so I just took two, so instead of 4, I took 2 because the hours. Because it was easier for me to finish 26 hours with two courses. It was a lot. I think that's why I've been taking too long to finish this, because I can't do the hours. It's hard. It is hard, and I know it's helpful and I don't my concern is not they don't help, because they do help, they do. But I think they require, it's like too much hours for me that I work. Because there's a lot of students they come and just study, you know, so that's good for them.

\section{Completer Recommendations}

The recommendations made by completing students reflect the strategies that helped them to stay in the course until the end of the term.

1. Plan out the term with the help of a counselor

2. Connect with classmates who you can study with

3. Keep your focus on your goal

4. Try to finish this (ESL classes) because if you don't have the language, you can’t do your career 
5. Do homework and prepare for your class

6. Speak to someone, “maybe the solution is there and you don't know. You have to speak."

\section{Non-completer Characteristics}

The students who withdrew before the end of the term of study also shared two common characteristics. With the exception of one student who did not work, the other five students worked full-time jobs; three of the six students worked 40 hours each week, and one of the six students worked 60 hours each week. The student who worked 28 hours each week and the three students who worked 40 hours each week did not feel that their jobs interfered much with their school work. The second shared characteristic among the six students interviewed was a lack of expressed goal commitment. In five of the six interviews, none of the interview questions elicited any expression of direct or indirect goal commitment. Students spoke of the desire to "do good on my homework," "learn more,” "find somebody tutor, somebody help me," and "pay more attention.” However, only one non-completing student expressed a commitment to the goal of getting a degree.

When non completing students were asked about a fellow student who was helpful in the term of withdrawal, five of the six did not respond readily. One student reported that her sister-in-law was also her classmate; "we study together, sometimes when I don't understand something, she say me, and I help you.” She elaborated that her sister-in-law likes reading and the student likes grammar; so "she help me in reading and I help in grammar.” When another non completing student was probed on this question, 
she reluctantly offered, "ahm, I had a friend from the class, we used to study together for the class." She was not specific about who the friend was or what they studied together. Non-completer Concerns

Whereas an insufficiency of time for school, work, and family preoccupied the term completers as well, the non completers were more concerned with the lack of English competency and good grades. One interviewee felt that she was not learning any English. "I don’t have practice because I work with Spanish people and my friends, my family is Spanish. I don't have practice.” This student concluded that "I’m here for learning, no for passing." Another student lived in the United States for 9 years before starting to study English; after enrolling in college at the first level, she stopped out for two semesters between the second and the third levels. Her concern is that she has regressed and would like to start at the first level again because "I forget some stuff." The only student among the non-completers who did not work, also felt that she "had no time to do work for my class and what is required for my class and what is required by my professor.” This student's concern came from her initial placement at the fourth level. She felt that because she had not taken classes in the lower levels like the other students, she was less prepared in the structure of the English language than the other students were.

Getting bad grades was another concern shared by four of the six non completing students, and in the case of three of them, it was the reason they gave for withdrawing from the course. Beyond the fear of receiving a failing grade, there was a variety of other reasons that contributed to the student's decision to withdraw. These reasons are summarized in Table 14. 
Table 14

Reasons for Not Completing the Course

Student Reason

\#1 Student's daughter broke her hand, the student was also sick, and there was no time to do schoolwork

\#2 Student failed the first two tests and was afraid she would not do well in the course

\#3 Student had a family emergency in his country and missed 2 weeks of class while he was gone

\#4 Student missed too many classes because of family problems

\#5 Student was not confident at the level where she was placed

\#6 Student did not like the professor

\section{Non-completer Recommendations}

The non-completing students who were interviewed were all concerned about doing well in their class. It was logical to elicit their opinion on what would help them to do well, especially if that factor was missing from their college experience in the non completed term. As was expected, their responses varied. One very expressive interviewee whose initial placement was at the fifth level, suggested that too much was assumed in-terms of what new students knew, and suggested that all instructors start the term with a review of the previous level. Another student offered a similar recommendation based on the fact that every class has students who are new to the college and not continuing from the previous class. Students who withdrew because they 
were afraid of not doing well in the class admitted that they did not speak to the professor about their concerns. During the course of the interview, two students concluded that students should talk with the professor about their concerns before withdrawing from the class.

\section{Summary of Results}

This study examined factors that predicted in-term persistence for community college ESL students. Data was collected in two phases during the study. Phase 1 data were collected from a student questionnaire and existing college records, and Phase 2 data were collected from student interviews. Descriptive analysis was used to differentiate the variables and present the data in Phase 1, and constant comparative analysis was used to analyze the data collected in the interviews in Phase 2.

With the exception of two integration variables - language use to watch TV and language used on Internet - there were no significance findings in the analysis of the data collected in Phase 1. Analysis of the interview data collected in Phase 2 discovered several themes that differentiated completers from non completers. The first and major challenge expressed by all the students was not having enough time for school work, jobs and personal lives. However, while completing students met the challenge to manage limited time successfully, it was the greatest obstacle to in-term persistence for non completing students. Goal commitment emerged as a second differentiating theme between completers and non completers. While completing students were focused on finishing the course as an important step towards their goal, non completing students were focused on either how fast they were learning English, what grade they would receive, or whether or not they liked the professor. Finally, the low level of integration as 
expressed in the lack of connection beyond the classroom to any college employee, differentiated in-term completers from non completers.

Chapter V summarizes the study and discusses the findings. In addition, conclusions based on the results, limitations and delimitations of the study, and recommendations for further research and practices are presented and discussed. 


\section{Chapter V}

\section{Discussion}

This chapter reviews the background and purpose of this study as well as discusses the findings and conclusions based on the results of the study. Suggestions for future research as well as recommendations for practice are presented. Limitations of the study that impact the application of these recommendations are reviewed and discussed.

\section{Summary of the Study}

\section{Background and Purpose of the Study}

Community colleges serving ESL students continue to invest time and resources in planning programs to meet the academic needs of language-minority students. The preparation, qualification and experience for instructors of ESL have been improved, increased, and enhanced to result in a superior delivery of English instruction to the ESL student population. Nonetheless, colleges still seek new and different ways to encourage and facilitate persistence among language-minority students.

Persistence studies have characteristically focused on either fall to spring persistence, freshman to sophomore persistence, or freshman to graduation persistence. However, the single most significant step to getting students to the goal of graduation or program completion is getting students to complete the course(s) for which they enroll

each semester. As a result, predictors of in-term persistence and variables that contribute to successful in-term persistence are critical to an overall retention program as well as to ultimate student success.

This study identified the need for research that focuses on the persistence of students from start to completion of a term, and the variables that differentiate those 
students who complete the term from those students who withdraw during the term. The identification of those variables and factors will facilitate the institution's planning for programs and intervention strategies designed to increase student persistence. To this end, the main research question in this study was aimed at the identification of selected factors that differentiate ESL students enrolled in a community college's English for Academic Purposes program who persist to term completion from those who do not persist to term completion.

\section{Findings and Conclusions}

ESL students at Broward College (formerly Broward Community College) enrolled in levels two through six were invited to participate in this study. A mixed methods research design consisting of two phases was utilized. Phase 1 collected data from the sample population ( $n=208)$ using the Community College ESL Student Questionnaire, where participants reported demographic, entry characteristics, goal commitment, and integration information. Phase 2 utilized a qualitative approach with a purposeful sample of 12 students, comprised of six students who withdrew during the term and six students who completed the term. These 12 students participated in individual, semi-structured funnel-sequenced interviews designed to discover deeper and richer information not disclosed in the questionnaire.

Of the 208 students who participated in the study and completed the Community College ESL Student Questionnaire in Phase 1, 202 students completed the course in which they were enrolled and six students withdrew from the course before the end of the term. There were 13 other students who made a very early decision to withdraw from the course in which they were enrolled. These students did not participate in the Phase 1 
survey. Because of the final distribution of completers and non completers, only two significant findings were generated by the analysis of the data collected in Phase 1 . Language used to watch TV and language used on the internet are integration variables, and were found to be significant at .024 and .028 respectively.

Analysis of the data collected from the interviews during Phase 2 yielded more relevant information that is valuable for the purpose of the study. Several themes emerged that were shared among all participants, while other themes were consistently different between completers and non completers. The first and major challenge expressed by all the students was not having enough time for school work, jobs and personal lives. While all the students faced the challenge of managing limited time successfully, the demands of life beyond their coursework seemed to be more pressing for non completing students. Beyond the press of time and the concerns of their personal lives, stated commitment to a goal emerged in the interviews as one of the outstanding differences between those students who completed and those students who did not complete the course in which they were enrolled. Completing students were able to clearly identify a goal and make the connection between completing this course and achieving that goal. Finally, completing students exhibited a greater level of integration as expressed in the connection to college employees other than their instructor.

The data generated by this study agrees with the existing general persistence literature (Pascarella et al., 2003; Stage, 1989; Tinto, 1993). These students were shaped by a variety of atributes and experiences acquired before entering the community college. They have concerns that are common to all college students of financing their education and managing the many demands on their time. Many of them must work in order to stay 
in college and part time employment is often an unaffordable luxury. In addition, English-as-a-second-language students are caught in a double academic bind, in that they are considered as both pre-college students and remedial students (Rendón, 1994). Because this multiplies the at-risk category for the ESL student, it also often divides their chances of completion. All the interviewees shared an overriding concern to be competent in English and to protect their GPA. The ability to connect with an academic or financial aid advisor, as well as the ability to identify and visualize a goal of completion, emerged as the differentiating factors between the students interviewed who completed the course in which they were enrolled and the ones who did not complete the course.

\section{Recommendations for Future Research and Practice}

A review of the literature revealed a general need for studies on ESL students' program and degree completion. A better understanding of the short term goals as well as ultimate educational goals of ESL students enrolling in the community college will discover students intentions and determine program planning and educational support for these students' success. Cohen and Brawer’s (2003) indication that students use community colleges for their purposes, and frequently achieve those purposes short of program completion (p. 57), is just as true for ESL students as it is for the general community college student population. However, the assumption that all ESL students are on a degree completion track continue to mislead program administrators and result in confusing counsel to students as they pursue their individual enrollment purposes.

Recommendations for future research include regular follow up studies with students who withdraw in the course of the term, whether or not they enroll in the 
subsequent term. Additional research should also be done on the impact of students' entering goals on in-term persistence. There is anticipated growth in the numbers of second language students attending community colleges in south Florida, and therefore continued research focusing on those factors that encourage and facilitate in-term persistence for this student population is needed. Studies that examine the relationship between ESL students' goal articulation and their connection with one or more college employees would give valuable insight to the institution and to the students. Finally, future research that looks at the differences in ESL student persistence between varying sessions (i.e., 6 weeks, 8 weeks, twelve weeks and sixteen weeks) holds an impact for advising, scheduling and student success.

\section{Implications for Practice}

The results of this study suggest that enhancement in two areas can assist students in better planning and goal articulation. First, a prescribe schedule of visits with an advisor or success specialist will provide structure to course scheduling for program completion. Once the student is able to visualize the program and locate themselves within it, they will be better able to articulate their academic goals. Another discovery resulting from the study is the need to provide opportunities on campus for the ESL student to communicate in English outside of the classroom. This should inform the institution in its program and support planning for this student population.

Also, an early identification of students' goals for enrolling in ESL classes and attending the community college will assist faculty, staff and administrators to monitor student progress towards fulfilling those individual goals. Other than the pursuit of a college degree, study participants included the following among their goals for enrolling 
in ESL classes: to improve English language skills, to satisfy a social or cultural interest, and to learn enough English to get a job. Many participants were not employed, were not seeking employment, and were not pursuing a college degree; they were enrolled in ESL classes because they had young children in elementary school, who no longer spoke their primary language exclusively. These children were beginning to insist that their parents speak English with them at home

This study also showed that establishing a relationship with a faculty or an advisor facilitated students' in-term persistence. The literature supports the fact that proactive staff increase retention rates (Brier, Hirschy, \& Braxton, 2008), and this finding can inform program administrators and advisors about reasons that motivate ESL students to persist. Colleges that are able to translate the skills applied to retaining students from year to year, to retaining them from start to end of term, will experience an increase in overall student retention, and subsequently, student completion and graduation.

\section{Limitations}

According to Creswell (1994), researchers use limitations to mention potential weaknesses of the study and delimitations to narrow the scope of the study. The limitations of this study are present in the nature and size of the sample and the incompleteness of the data provided by the participants. The sample for this study was drawn from one session of one term of one campus of one institution, and therefore results may not be generalizable to broader ESL community college populations. The low number of non completing participants restricts analysis and comparisons between completers and non completers. Though retention is a campus-based phenomenon 
(Berger \& Lyon, 2005), and no two campus populations are exactly alike, the results of this study best serves this campus and this institution.

A second limitation resulted from the percentage of missing data values for some of the variables. For example, research studies have identified parental education as a predictor of student persistence (Elkins, Braxton, \& James, 2000), but too many values were missing for this variable to calculate its significance in this study. A review of the responses to the survey questions and the transcript of the individual interviews, displayed a low level of English proficiency on the part of study participants. This restricted full and complete responses on all the variables

Even though the distribution between completing and non completing students for the term of study was heavily in favor of completing students, the study was carried out as designed for the following reasons. First, the sample population is representative of the ESL population at the college in all its demographic descriptive, and therefore the only value to be added by collecting data in another term would be a slightly larger number of student participants. Also, data collected in a subsequent term would be largely from students who had already participated in the first survey, and who have or have not completed the term for the second survey. Finally, the extension of the study beyond one term would alter the design of the study and fail to capture the in-term persistence of a sample of the ESL student population at the college.

\section{Summary}

This study contributed to the body of research that investigated entry characteristics, goal commitment, and integration factors as predictors of in-term persistence for community college English-as-a-second-language students. This ESL 
population is sufficiently diverse in entry characteristics to be representative of any community college ESL student population. They are also consistently diverse in the goals with which they enroll in the community college; as many ESL students as are pursuing a degree, are pursuing some goal other than program completion or graduation. Many ESL students are professionals who seek the level of English necessary to practice their profession in the United States. This diversity of goals is often the key to their persistence. The level of integration discovered by the study identified an area of need that the college might choose to address in future planning to serve this segment of its student population. 


\section{REFERENCES}

Alfonso, M. (2006). Hispanic educational attainment in sub-baccalaureate programs. New Directions for Community College, 133, 17-25.

American Association of Community Colleges. (2005). National profile of community colleges: Trends and statistics (4th ed.). Washington, DC: Community College Press.

American Association of Community Colleges. (2009). Community college facts at a glance. Retrieved from http://www.aacc.nche.edu/AboutCC/Documents/fastfacts2009.pdf

Ary, D., Jacobs, L. C., \& Razavieh, A. (2002). Introduction to research in education, (6th ed.). Belmont, CA: Wadsworth.

Astin, A. W. (1972). College dropouts: A national profile. ACE Research Reports, 7(1). Washington, DC: American Council on Education.

Astin A. W. (1993). What matters in college: Four critical years revisited. San Francisco, CA: Jossey-Bass.

Astin, A. W. (1995). How good is your institution's retention rate? Research in Higher Education, 38, 647-658.

Bailey, T., \& Weininger, E. (2000, December). Performance, graduation, and transfer of immigrants and natives in City University of New York community colleges. Paper presented at the New Immigrants in New York: Incorporation of Recent Immigrants in New York City Conference, New York.

Barbatis, P. (2010). Underprepared, ethnically diverse community college students: Factors contributing to persistence. Journal of Developmental Education, 33, 1424.

Barnett, E. (2007). Validating experiences and persistence among urban community college students: A case study. Community College Journal of Research and Practice, 24, 567-576.

Bean, J. P. (1980). Dropouts and turnover: The synthesis and test of a causal model of student attrition. Research in Higher Education, 12, 155-187.

Bean, J. P. (1990). Why students leave: Insights from research. In D. Hossler (Ed.), The strategic management of college enrollments (pp. 147-169). San Francisco, CA: Jossey-Bass. 
Bean, J. P., \& Metzner, B. S. (1985). A conceptual model of nontraditional student attrition. Review of Educational Research, 55, 485-540.

Berger, J. B., \& Lyon, S. C. (2005). Past to present: A historical look at retention. In A. Seidman (Ed.), College student retention (pp. 1-29). Westport, CT: Praeger Publishers.

Bers, T. H., \& Smith, K.E. (1991). Persistence of community college students: The influence of student intent and academic and social integration. Research in Higher Education, 32, 539-556.

Betances, S. (2004.). How to become an outstanding educator of Hispanic and African American first-generation college students. In F.W. Hale Jr. (Ed.), What makes racial diversity work in higher education (pp. 44-59). Sterling, VA: Stylus.

Blumenthal, A. J. (2002). English-as-a-second-language at the community college: An exploration of context and concerns. New Directions for Community Colleges, $117,45-54$.

Bonham, L. A., \& Luckie, J. I. (1993). Community College retention: Differentiating among stopouts, dropouts, and optouts. Community College Journal of Research and Practice, 17, 543-554.

Borglum, K., \& Kubala, T. (2000). Academic and social integration of community college students: A case study. Community College Journal of Research and Practice, 24, 567-576.

Braxton, J. M., Hirschy, A. S., \& McClendon, S. (2004). Understanding and reducing college student departure. Ashe-Eric Higher Education Reports, 30, 1-97.

Braxton, J. M., \& Lee, S. D. (2005). Toward reliable knowledge about college student departure. In A. Seidman (Ed.), College student retention: Formula for success. (pp. 107-128). Westport, CT: Praeger.

Braxton, J. M., Sullivan, A. V. S., \& Johnson, R. M. (1997). Appraising Tinto's theory of college student departure. Higher Education Handbook of Theory and Research, $12,107-164$.

Brier, E. M., Hirschy, A. S., \& Braxton. J. M. (September-October 2008). The strategic retention initiative: Theory-based practice to reduce college student departure. About Campus, 18-20.

Broward College. (2008). Mission statement. Retrieved from www.broward.edu/view/mission.jsp 
Cabrera, A. F., Nora, A., \& Castañeda, M. B. (1993). College persistence: Structural equations modeling test of an integrated model of student retention. Journal of Higher Education, 64, 123-139.

Carter, D. F. (2006). Key issues in the persistence of underrepresented minority students. New Directions for Institutional Research, 130, 33-46.

Chang, J. C. (2005). Faculty-student interaction at the community college: A focus on students of color. Research in Higher Education, 46, 769-802.

Chase, A. M., \& Mahoney, J. R. (Eds.). (1996). Global awareness in community colleges: A report of a national survey. Washington, DC: American Association of Community Colleges.

Cofer, J., \& Somers, P. (2001). What influences student persistence at two-year colleges? Community College Review, 29, 56-77.

Cohen, A. M., \& Brawer, F. B. (2003). The American community college. (4th ed.) San Francisco, CA: Jossey-Bass.

Community College Survey of Student Engagement, University of Texas. (2002). Focusing on the face of the future. CCSE Highlights (Issue Brief Vol. 1, Issue 2). Austin, TX: Author.

Cope, R. G., \& Hannah, W. (1975). Revolving college doors. New York, NY: John Wiley \& Sons.

Creswell, J. W. (1994). Research design: Qualitative and quantitative approaches. Thousand Oaks, CA: Sage.

Creswell, J. W., \& Miller, D. L. (2000). Determining validity in qualitative inquiry. Theory into Practice, 39, 124-130.

Creswell, J. W., \& Plano Clark, V. L. (2007). Designing and conducting mixed methods research. Thousand Oaks, CA: Sage.

Cross, K. P. (1976). Accent on learning. San Francisco, CA: Jossey-Bass.

Daniels, G. (1990, October). Student intention and retention in a community college setting. Paper presented at NEAIR 17th Annual Conference, Albany, NY.

Davis-Wiley, P. (2002). A demographic profile of diversity in the United States: Who are the newcomers of the 21st century? International Education, 32, 49-57.

Denzin, N. K. (1989). Interpretive interactionism. Newbury Park, CA: Sage. 
Driscoll, A. K. (2007). Beyond access: How the first semester matters for community college students' aspirations and persistence. PACE Policy Brief 07-2, August 2007, pp. 2-14.

Elkins, S. A., Braxton, J. M., \& James, G. W. (2000). Tinto’s separation stage and its influence on first-semester college student persistence. Research in Higher Education, 41, 251-268.

Ellis, P., \& Stebbins, C. (1996). Providing access to linguistically diverse students. Community College Review, 24, 3-19.

Erisman, W., \& Looney, S. (2007). Opening the door to the American dream: Increasing Higher education and success for immigrants. Washington, DC: Institute for Higher Education Policy.

Escobedo, G. (2007). A retention/persistence intervention model: Improving success across cultures. Journal of Developmental Education, 31, 12-17.

Faltis, C. J. (2001). Joinfostering: Teaching and learning in multilingual classrooms (3rd ed.) Upper Saddle River, NJ: Merril Prentice Hall.

Fike, D. S. (2008). Predictors of first-year student retention in the community college. Community College Review, 36, 68.

Fox, R. (1986). Application of a conceptual model of college withdrawal to disadvantaged students. American Education Research Journal, 23, 415-424.

Glaser, B. G., \& Strauss, A. L. (1967). The discovery of grounded theory: Strategies for qualitative research. New York, NY: Aldine Publishing Company.

Grimes, S. K., \& Antworth, T. (1996). Community College withdrawal decisions: Student characteristics and subsequent reenrollment patterns. Community College Journal of Research and Practice, 20, 345-361.

Guiffrida, D. A. (2006). Toward a cultural advancement of Tinto's theory. The Review of Higher Education, 29, 451-472.

Hagedorn, L. S., Chi, W. Y., Cepeda, R. M., \& McLain, M. (2007). An investigation of critical mass: The role of Latino representation in the success of urban community college students. Research in Higher Education, 48, 73-91.

Halpin, R. L. (1990). An application of the Tinto model to the analysis of freshman persistence in a community college. Community College Review, 17, $22-33$. 
House, J. D. (1998). The effects of entering characteristics and instructional experiences on student satisfaction and degree completion: An application of the inputenvironment-outcome assessment model. International Journal of Instructional Media, 26, 423-434.

Hoyt, J. E. (1999). Remedial education and student attrition. Community College Review, 27, 51-72.

Hurtado, S., \& Carter, D. F. (1996). Latino students' sense of belonging in the college community: Rethinking the concept of integration on campus. In F. K. Stage, G. L. Anaya, J. P. Bean, D. Hossler, \& G. Kuh (Eds.), College students: The evolving nature of research (pp. 123-136). Needham Heights, MA: Simon \& Schuster Publishing.

Janesick, V. J. (1994). The dance of qualitative research design: Metaphor, methodolatry, and meaning. In N. K. Denzin \& Y. S. Lincoln (Eds.), Handbook of qualitative research (pp. 208-235). Thousand Oaks, CA: Sage.

Jenkins, D. (2007). Institutional effectiveness and student success: A study of high and low-impact community colleges. Community College Journal of Research and Practice, 31, 945-962.

Johnson, J. L. (1997). Commuter college students: What factors determine who will persist and who will drop out? College Student Journal, 31, 323-332.

Kangas, J. A., \& Budros, K. (1993). ESL persistence: A summary report. Research report. San Jose Evergreen Community College. San Jose, CA: Author.

Kim, K. A. (2002). Exploring the meaning of "nontraditional" at the community college. Community College Review, 30, 74-89.

Laden, B. V. (2004). Serving emerging majority students. New Directions for Community Colleges, 127, 5-19.

Leinbach, D. T., \& Bailey, T. R. (2006). Access and achievement of Hispanics and Hispanic immigrants in the City University of New York. New Directions for Community Colleges, 133, 27-40.

Lewis, M. (2009). “To triumph in my life”: ESL students define success. In K. Bailey, \& M. Santos (Eds.), Research on ESL in U.S. community colleges: People, programs, and potential. (pp. 158-169). Ann Arbor, MI: The University of Michigan Press.

Lincoln, Y., \& Guba, E. (1985). Naturalistic inquiry. Beverly Hills, CA: Sage. 
Liu, E., \& Liu, R. (1999). An application of Tinto’s model at a commuter campus. Education, 119, 537-541.

Mery, P. M. (1995). City College of San Francisco credit ESL course completion (Res. Tech. Rep. No. 143). San Francisco, CA: Office of Institutional Development, Research and Planning.

Miller, M. T., Pope, M. L., \& Steinmann, T. D. (2005). Dealing with the challenges and stressors faced by community college students: The old college try. Community Education, 39, 419-455.

Mulligan, S.C., \& Hennessy, J. J. (1990, April). Persistence in a community college: Testingattrition models. Paper presented at the annual meeting of the American Educational Research Association, Boston, MA.

Murphy, K. B. (2006, May). Factors affecting the retention, persistence, and attainment of undergraduate students at public urban four year higher education institutions. Paper presented at the Annual Forum of the Association for Institutional Research (AIB), Chicago, IL.

National Center for Education Statistics. (2005 Integrated postsecondary education data system (IPEDS) fall enrollment survey [Data file]. Washington, DC: U.S. Department of Education.

National Center for Education Statistics. (2008). The condition of Education 2008. Retrieved from http://nces.ed.gov/pubsearch/pubsinfo.asp?pubid=2008031

O’Brien, N. P., \& Collins, J. (Eds.). (2003). The Greenwood Dictionary of Education. Westport, CT: Greenwood Press.

Oliver-Hoyo, M., \& Allen, D. (2006). The use of triangulation methods in qualitative Educational research. Journal of College Science Teaching, 35, 42-47.

Otero, R., Rivas, O., \& Rivera, R. (2007). Predicting persistence of Hispanic students in their 1st year of college. Journal of Hispanic Higher Education, 6, 163-173.

Pascarella, E. T., \& Chapman, D. (1983). A multiinsittutional, path analytic validation of Tinto's model of college withdrawal. American Educational Research Journal, 20, 87-102.

Pascarella, E. T., Smart, J. C., \& Ethington, C. A. (1986, February). Long-term persistence of two- year college students. Paper presented at the Annual Meeting of the Association for the Study of Higher Education. San Antonio, TX. 
Pascarella, E. T., \& Terenzini, P. (1980). Predicting persistence and voluntary dropout decisions from a theoretical model. Journal of Higher Education, 61, 60-75.

Pascarella, E. T., \& Terenzini, P. T. (1991). How college affects students: Findings and insights from twenty years of research. San Francisco,CA: Jossey-Bass.

Pascarella, E. T., \& Terenzini, P. T. (1998). Studying college students in the 21st Century: Meeting new challenges. Review of Higher Education. 21, 151-165..

Pascarella, E. T., Wolniak, G. C., \& Pierson, C. T. (2003). Influences on community college students' educational plans. Research in Higher Education, 44, 301-314.

Reason, R. D., Terenzini, P. T., \& Domingo, R. J. (2006). First things first: Developing academic competence in the first year of college. Research in Higher Education, $47,149-175$.

Rendón, L. (1995, March). Facilitating retention and transfer for first generation students in community colleges. Paper presented at the New Mexico Institute, Rural Community College Initiative, Espanola, NM. (ERIC Document Reproduction Service No. ED383369)

Rendón, L. I. (1994). Validating culturally diverse students: Toward a new model of learning and student development. Innovative Higher Education, 19, 33-50.

Rendón, L. I. (2000). Academics of the heart. About Campus, 5, 3-5.

Rendón, L.I. (2002). Community College Puente: A validating model of education. Educational Policy, 16, 642-667.

Rendón, L. I., Jalomo, R. F., \& Nora, A. (2000). Theoretical considerations in the study of minority student retention. In J. Braxton (Ed.), Rethinking the departure puzzle: New theory and research on college student retention (pp. 127-156). Nashville, TN: Vanderbilt University Press.

Rickinson, B., \& Rutherford, D. (1995). Increasing undergraduate student retention rates. British Journal of Guidance and Counseling, 23, 161-172.

Roberts, J., \& Styron, R. (2010). Student satisfaction and persistence: Factors vital to student retention. Research in Higher Education Journal, 6, 1-18

Rodriguez, N. (1996). Predicting the academic success of Mexican Americans and White college students. Hispanic Journal of Behavioral Sciences, 18, 329-343.

Romano, R. M. (1995). First-year attrition and retention at a community college. Journal of Applied Research in the Community College, 2, 169-177. 
Rumbaut, R. G., \& Portés, A. (2001). Introduction - Ethnogenesis: Coming of age in immigrant America. In R. G. Rumbaut \& A. Portés (Eds.), Ethnicities: Children of immigrants in America (pp. 1-19). Berkeley, CA: University of California Press.

Schuyler, G. (1999). A historical and contemporary view of the community college curriculum. In G. Schuyler (Ed.), Trends in community college curriculum. New Directions for Community Colleges, No. 108. San Francisco, CA: Jossey-Bass.

Scoggin, D., \& Styron, R. (2006). Factors associated with student withdrawal from community college. The Community College Enterprise, Spring, 111-124.

Seidman, A. (2005). Where we go from here: A retention formula for success. In A. Seidman (Ed.). College student retention: Formula for student success. (pp. 296316). Westport, CT: Praeger Publishers.

Smith, A. B., Street, M. A., \& Olivarez, A. (2002). Early, regular, and late registration and community college student success: A case study. Community College Journal of Research and Practice, 26, 261-273.

Stage, F. K. (1989). Motivation, academic and social integration, and the early dropout. American Educational Research Journal, 26, 385-402.

Strauss, L. C., \& Volkwein, J. F. (2004). Predictors of student commitment at two-year and four-year institutions. The Journal of Higher Education, 75, 203-227.

Szelényi, K., \& Chang, J.C. (2002). Educating immigrants: The community college role. Community College Review, 30, 55-73.

Tanaka, G. (2002). Higher education's self-reflexive turn: Toward an intercultural theory of student development. The Journal of Higher Education, 73, 263-296.

Tashakkori, A., \& Creswell, J. W. (2007). Editorial: Exploring the nature of research questions in mixed methods research. Journal of Mixed Methods Research, (1), 37.

Tashakkori, A., \& Teddlie, C. (1998). Mixed methodology: Combining qualitative and quantitative approaches. Thousand Oaks, CA: SAGE Publications.

Tashakkori, A., \& Teddlie, C. (2009). Foundations of mixed methods research: Integrating quantitative and qualitative approaches in the social and behavioral sciences. Los Angeles, CA: SAGE Publications.

Shin, H.B., \& Bruno, R. (2003). Language use and English-speaking ability: 2000. Census 2000 Brief. U.S. Census Bureau, Washington, DC. 
Tinto, V. (1975). Dropout from higher education: A theoretical analysis of recent research. Review of Educational Research, 45, 89-125.

Tinto, V. (1987). Leaving College: Rethinking the causes and cures of student attrition. Chicago, IL: University of Chicago Press.

Tinto, V. (1993). Leaving College: Rethinking the causes and cures of student attrition. (2nd ed.), Chicago, IL: The University of Chicago Press.

Tinto, V. (1996). Restructuring the first year of college. Planning for Higher Education, 25, 1-6.

Tinto, V. (2002). Enhancing student persistence: Connecting the dots. A conference sponsored by the Wisconsin Center for the Advancement of Postsecondary Education, The University of Wisconsin, Madison, WI, October 23-25, 2002.

Witt, A. A., Wattenbarger, J. L., Gollattscheck, J. F., \& Suppger, J. E. (1994). America's community college: The first century. Washington, DC: Community College Press. 
Appendix A

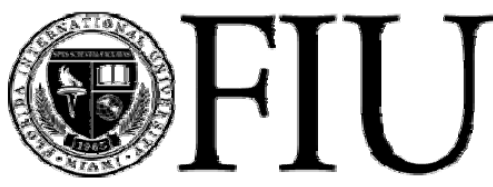

FLORIDA INTERNATIONAL UNIVERSITY

Miamis public research uninersity

\section{INFORMED CONSENT TO PARTICIPATE IN A RESEARCH STUDY}

Title of the Study: Predicting the In-Term Persistence of Community College English-as-aSecond-Language Students

Principal Investigator: Carolyn Tonge (email:ctonge@broward.edu) You are invited to be a part of a research study about factors that predict ESL students' persistence at Broward College.

You were chosen for the study because you are registered in an ESL course or courses at Broward College in the summer of 2009.

The Study: The purpose of this study is to learn about the factors that help ESL students to stay in school until the completion of the term. You will be asked to complete a questionnaire, and you may be invited to participate in an individual interview. The interview will be tape-recorded.

Risks: There is no known risk in this study.

Benefits: Participants will benefit from a better understanding of the factors that help them to persist. There will be no cost or compensation for participation in the study.

Confidentiality: All information will be handled in a strictly confidential manner. All the data collected will be kept in a locked file, and only the researcher will have access to the file.

Voluntary nature/questions: Participation in the study is voluntary, and you can choose not to participate without any negative consequences. If you want to withdraw your participation after you have completed the questionnaire, let the researcher know and she will destroy your questionnaire.

If you would like more information about this study when it is completed, you may contact me at (954) 201-6378 or ctonge@broward.edu. If you feel that you are mistreated or would like to talk with someone about your rights as a volunteer in this research study, you may contact Dr. Patricia Price, the Chairperson of the Florida International University Institutional Review Board at 305348-2618 or 305-348-2494. You may also contact Mr. Matthew Seeman, the Assistant Director for Research at Broward College (954-201-7985).

I understand the study described above. I am 18 years of age or older and I agree to participate. 
Appendix B

COMMUNITY COLLEGE ESL STUDENT QUESTIONNNAIRE

Course ID

Student ID

What is your gender?

Male Female

What is your age?

What is your marital status?

What is your country of birth?

What is your native language?

What is your racial/ethnic identification?

Asian or Pacific Islander

Black non Hispanic

Hispanic/Latino

White non Hispanic

American Indian or Alaska Native

Other

How many hours do you work per week?

If you work, does your job affect your college work?

No, I don't feel that my job interferes much with my school work

Yes, my job takes some time from my school work

Yes, my job takes a lot of time from my school work

Where did you complete high school?

How many years of schooling did your mother have?

How many years of schooling did your father have?

How many credits are you taking this term?

When do the classes you are now taking meet? 
_day only __ evening only ___ some day and some evening

How many hours per week do you usually spend studying or preparing for your classes?

How many years did you study English before coming to the U.S.?

How long did you study English in the U.S. before this semester?

What is the highest educational level you plan to complete?

This course only

All the ESL courses

Bachelor's Degree or higher

Why are you attending college at this time?

\section{(rank order up to 3 )}

To improve my English language skills

To satisfy a personal interest (cultural or social)

To obtain skills necessary to get a job

To obtain the skills necessary to retrain, remain current, or advance in a current job

To obtain an Associate Degree

To prepare to transfer to a four-year college or university

Other reason

Check the answer that fits best

\begin{tabular}{|l|l|l|l|}
\hline $\begin{array}{l}\text { What language do you } \\
\text { usually use in your daily } \\
\text { activities: }\end{array}$ & $\begin{array}{c}\text { More native } \\
\text { language }\end{array}$ & $\begin{array}{c}\text { More } \\
\text { English }\end{array}$ & $\begin{array}{c}\text { Both native } \\
\text { language and } \\
\text { English }\end{array}$ \\
\hline $\begin{array}{l}\text { Daily interactions with your } \\
\text { family }\end{array}$ & & & \\
\hline $\begin{array}{l}\text { Daily interactions with your } \\
\text { friends }\end{array}$ & & & \\
\hline $\begin{array}{l}\text { Daily interactions at your } \\
\text { work }\end{array}$ & & & \\
\hline Watching TV & & & \\
\hline Watching cable TV (if any) & & & \\
\hline Listening to radio/music & & & \\
\hline Using the internet & & & \\
\hline
\end{tabular}

Most of your friends are: (check the answer that fits best)

People who speak your native language and share your native culture

People who speak a different language from a different culture, not American

Americans who speak the same language as you

Americans who speak English

About how many hours a week do you usually spend on the college campus, not counting time attending classes or lab? 
How often have you visited your advisor/Success Specialist this term?

Check the answer that fits best

\begin{tabular}{|l|l|l|l|}
\hline $\begin{array}{l}\text { When I think about my experience at BC, } \\
\text { I would say that I. ... }\end{array}$ & Often & Occasionally & Never \\
\hline Participated in class discussions & & & \\
\hline $\begin{array}{l}\text { Studied course material with other } \\
\text { students }\end{array}$ & & & \\
\hline $\begin{array}{l}\text { Asked an instructor about course content } \\
\text { or grade }\end{array}$ & & & \\
\hline Met with an instructor in his/her office & & & \\
\hline $\begin{array}{l}\text { Discussed educational or career plans with } \\
\text { an instructor }\end{array}$ & & & \\
\hline $\begin{array}{l}\text { Talked informally with an instructor about } \\
\text { common interests or current events }\end{array}$ & & & \\
\hline $\begin{array}{l}\text { Discussed academic performance, } \\
\text { academic difficulties, or personal } \\
\text { problems with an instructor }\end{array}$ & & & \\
\hline $\begin{array}{l}\text { Used email to communicate with my } \\
\text { instructor }\end{array}$ & & & \\
\hline Used the library & & & \\
\hline Used the cafeteria & & & \\
\hline $\begin{array}{l}\text { Attended meetings of student } \\
\text { organizations or clubs }\end{array}$ & & & \\
\hline $\begin{array}{l}\text { Participated in events sponsored by a } \\
\text { student organization or club }\end{array}$ & & & \\
\hline
\end{tabular}

Check the one answer that fits best

\begin{tabular}{|l|l|l|l|l|}
\hline $\begin{array}{l}\text { When I think about my } \\
\text { experiences at BC, I would say } \\
\text { that ... }\end{array}$ & $\begin{array}{c}\text { Strongly } \\
\text { Agree }\end{array}$ & Agree & Disagree & $\begin{array}{c}\text { Strongly } \\
\text { Disagree }\end{array}$ \\
\hline $\begin{array}{l}\text { My instructors generally remember } \\
\text { my name }\end{array}$ & & & & \\
\hline $\begin{array}{l}\text { I receive prompt feedback from } \\
\text { instructors on my performance }\end{array}$ & & & & \\
\hline $\begin{array}{l}\text { My instructors understand that } \\
\text { students come from different } \\
\text { backgrounds }\end{array}$ & & & & \\
\hline I am encouraged by my instructors & & & & \\
\hline
\end{tabular}




\begin{tabular}{|l|l|l|l|l|}
\hline to openly share my views in class & & & & \\
\hline $\begin{array}{l}\text { I feel like my personal and family } \\
\text { history is valued in class }\end{array}$ & & & & \\
\hline $\begin{array}{l}\text { I feel that I am a member of the } \\
\text { campus community }\end{array}$ & & & & \\
\hline $\begin{array}{l}\text { I've had at least one instructor at } \\
\text { this college whom I thought of as a } \\
\text { mentor }\end{array}$ & & & & \\
\hline
\end{tabular}

How long have you lived in the U.S.?
less than one year
1-4 years
5-10 years
10 years +

Which of the following best describes your current immigration/residency status?

U.S. resident/citizen

In the process of obtaining residency

International student (F-1 or J-1 visa)

_ Visitor (visa)

_ Political asylee/refugee 


\section{Appendix C}

\section{Semi-structured Interview Guide}

Thank you for agreeing to participate in this interview. The purpose of this interview is to learn more about you and the experiences you encountered during your summer term at Broward College. I will begin with some general questions about you and then we will start talking about your college experiences.

- Do you have any questions before we begin?

- Background Questions

1. Tell me about your educational experiences before you came to Broward College.

- Goal Commitment Questions

1. When did you register for the term?

2. Could you describe some of the concerns you have around attending college?

3. (for completers) Could you describe some things you would recommend to another student to help him/her stay in school until the end of the term? (for non-completers) Could you describe some of the reasons why you stopped attending classes this term?

- Integration Questions

1. Could you describe one social or educational experience you had this term that made you feel good about attending college?

2. Tell me about one college employee (faculty, staff, or administrator) who was helpful to you this term.

3. Tell me about one fellow student who was helpful to you this term.

- Is there anything else you would like to tell me about your term experience at Broward College?

- Do you have any questions before we end?

Thank you very much for participating in this study 
VITA

\section{CAROLYN TONGE}

Born, Corn Island, Nicaragua

1971

B.A., English \& Bible

Nyack College

Nyack, New York

$1971-1975$

Assistant Higher Education Officer

Teacher Education Department

Medgar Evers College, CUNY

Brooklyn, New York

1976

M.A., Spanish \& Education

The City College, CUNY

New York, New York

$1976-1980$

$1980-1995$

$1981-1986$

Assistant Dean

School of Education and Human Services

St. John's University

Queens, New York

Independent Contractor, Translation and Editing United Nations, Reports Division

New York, New York

Advertising AE on IBM Accounts

Lord, Geller, Federico \& Einstein

(Subsidiary of J Walter Thompson NY)

New York, New York

$1987-1995$

Campus Director and Assistant Dean

College of New Rochelle

School of New Resources

New Rochelle, New York

1995- 1997

Assistant to the President

College of New Rochelle

New Rochelle, NY 


$\begin{array}{ll}1998-1999 & \begin{array}{l}\text { Dean, School of Adult Degree and Continuing Education } \\ \text { (formerly ADCP) } \\ \text { Nyack College } \\ \text { Nyack, New York }\end{array} \\ 2000-2001 & \begin{array}{l}\text { Adjunct Faculty, ESL } \\ \text { Broward Community College } \\ \text { Davie, Florida }\end{array} \\ 2001-\text { Present } & \begin{array}{l}\text { Associate Dean for Academic Affairs } \\ \text { ESL/Reading/SLS Department } \\ \text { Broward College, Central Campus } \\ \text { Davie, Florida }\end{array}\end{array}$

